\title{
The effect and mode of action of saponins on the microbial populations and fermentation in the rumen and ruminant production
}

\author{
A. K. Patra ${ }^{1} *$ and J. Saxena ${ }^{2}$ \\ ${ }^{1}$ Department of Animal Nutrition, West Bengal University of Animal and Fishery Sciences, Belgachia, Kolkata, India \\ ${ }^{2}$ Coskata, 4575 Weaver Parkway, Warrenville, Illinois 60555, USA
}

\begin{abstract}
The growing public concerns over chemical residues in animal-derived foods and threats of antibiotic-resistant bacteria have renewed interest in exploring safer alternatives to chemical feed additives in ruminant livestock. Various bioactive phytochemicals including saponins appear to be potential 'natural' alternatives to 'chemical' additives in modulating rumen fermentation favourably and animal performance. Saponins are a diverse group of glycosides present in many families of plants. The primary effect of saponins in the rumen appears to be to inhibit the protozoa (defaunation), which might increase the efficiency of microbial protein synthesis and protein flow to the duodenum. Furthermore, saponins may decrease methane production via defaunation and/or directly by decreasing the activities (i.e. rate of methanogenesis or expression of methane-producing genes) and numbers of methanogens. Saponins may also selectively affect specific rumen bacteria and fungi, which may alter the rumen metabolism beneficially or adversely. The ammonia-adsorption and modulation of digesta passage in the rumen by saponins have also been implicated in altering rumen metabolism, but their physiological responses are likely to be negligible compared with microbiological effects. The effects of saponins on rumen fermentation have not been found to be consistent. These discrepancies appear to be related to the chemical structure and dosage of saponins, diet composition, microbial community and adaptation of microbiota to saponins. There is need for systematic research based on chemical structures of saponins, nutrient composition of diets and their effects on rumen microbial ecosystem to obtain consistent results. The present paper reviews and discusses the effects and mode of action of saponins on microbial community and fermentation in the rumen, and ruminant performance.
\end{abstract}

\section{Saponins: Mechanisms of action: Microbial ecology: Rumen fermentation:} Ruminant production

\section{Introduction}

The term 'phytochemicals' is used to describe non-nutritive plant metabolites that are essential for the survival (i.e. protection against herbivores, pests and micro-organisms) and proper functioning of growth and reproduction in plants ${ }^{(1)}$. In recent years, there has been increasing interest among nutritionists and microbiologists to exploit bioactive phytochemicals such as saponins, condensed tannins and essential oils for improving rumen metabolism, and increasing the efficiency of ruminant production ${ }^{(2-7)}$. In particular, bioactive phytochemicals with selective antimicrobial properties can be of interest in animal nutrition $^{(3,8)}$. The impetus behind much of the research of using phytochemicals as feed additives has grown from the necessity of substituting chemical feed additives in animal agriculture because of growing concerns over chemical additives in terms of residues in animal products and the development of bacterial resistance to antibiotics ${ }^{(9)}$. This trend is likely to be continued due to growing demands for organic livestock products. Research is also increasingly being directed at avoiding undesirable impacts of ruminant production on the environment such as contributions to the greenhouse effect, and $\mathrm{N}$ and $\mathrm{P}$ pollution with the use of safer alternatives to chemical feed additives.

Saponins are a group of plant secondary compounds that have shown the possibility to modify rumen fermentation and enhance animal production ${ }^{(2-5,10-13)}$. Saponins of Yucca schidigera and Quillaja saponaria have been categorised as 'generally recognised as safe' for human consumption by the US Food and Drug Administration ${ }^{(14)}$.

Abbreviations: ppm, parts per million; VFA, volatile fatty acid

* Corresponding author: Dr Amlan K. Patra, fax + 9133 25571986, email patra_amlan@yahoo.com 
In recent years, a number of excellent reviews have been published on the potential use of saponins as rumen modifiers $^{(2,3,5)}$. However, the mechanisms of action of saponins and discrepancies of results among studies on rumen microbiota and fermentation have not been discussed in details in those reviews. The present review aims to provide deeper insights into the impacts of saponins on the rumen microbial community, how this community can influence rumen metabolism and fermentation, and how this might ultimately lead to improvements in ruminant performance. The recent investigations on the effects of saponins on ruminants are also reported in the present review.

\section{Chemistry of saponins}

The uses of saponins in traditional folk medicines and as a substitute for soap have been known for a long time. They occur in a wide variety of plants and also in some marine animals. Chemically, saponins are a group of highmolecular-weight glycosides in which saccharide chain units (1-8 residues) are linked to a triterpene (triterpene saponins) or steroidal (steroid saponins) aglycone moiety, i.e. sapogenin (Fig. 1). Triterpene saponins are more widely distributed in nature than steroidal types ${ }^{(15)}$. The steroidal moiety is in most cases in the furostanol or spirostanol form ${ }^{(15)}$. The saccharide chains are commonly attached at the $\mathrm{C}_{3}$ position (monodesmosidic), but some sapogenins contain two saccharide chains (bidesmosidic) attached at the

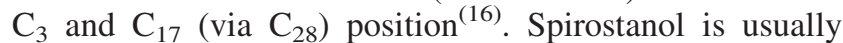
monodesmosidic and furostanol bidesmosidic in nature ${ }^{(15)}$. Most of the saponins are monodesmosidic or bidesmosidic. However, a lucerne and an Acacia auriculiformis saponin are tridesmosidic ${ }^{(16)}$. Spirostanol saponins are found mainly in the seeds, roots and bulbs of the plants, whereas furostanol saponins are present in the assimilatory parts of the plants ${ }^{(15)}$. The number of sugars, the type of sugars (for example, glucose, galactose, xylose, glucuronic acid and rhamnose) and the stereochemistry of the sapogenin moiety with functional groups $\left(-\mathrm{OH},-\mathrm{COOH},-\mathrm{CH}_{3}\right)$ vary greatly, producing a diverse group of metabolites in this compound class. The chemical structures of triterpene and steroidal saponins are described in detail elsewhere ${ }^{(15,16)}$.

\section{Effects of saponins on rumen microbial population}

\section{Ciliate protozoa}

A number of studies have demonstrated that pure saponins and saponin-containing plants or extracts have inhibitory effects on protozoa (Table 1) ${ }^{(17-43)}$. One of the earliest observations was made by Valdez et al. ${ }^{(29)}$ who showed that a commercial sarsaponin (steroidal spirostanol saponin) extracted from the Yucca schidigera plant decreased the protozoal population with a small increase in bacterial numbers in continuous culture systems. In many subsequent studies, the extracts of $Y$. schidigera have been shown to suppress the growth of rumen protozoa in vitro ${ }^{(44)}$ without affecting DM disappearance and other rumen microbial populations $^{(45)}$. The saponin-containing butanol extract of $Y$. schidigera has been shown to be responsible for all the plant's anti-protozoal activity ${ }^{(44,46)}$. Protozoal activity, as measured by the breakdown of $\left[{ }^{14} \mathrm{C}\right]$ leucine-labelled Selenomonas ruminantium in rumen fluid incubated in vitro, was stopped by the addition of $1 \%$ Y. schidigera extract $^{(44)}$. A number of in vivo studies have also confirmed the anti-protozoal effects of Yucca saponins $^{(43,47)}$.
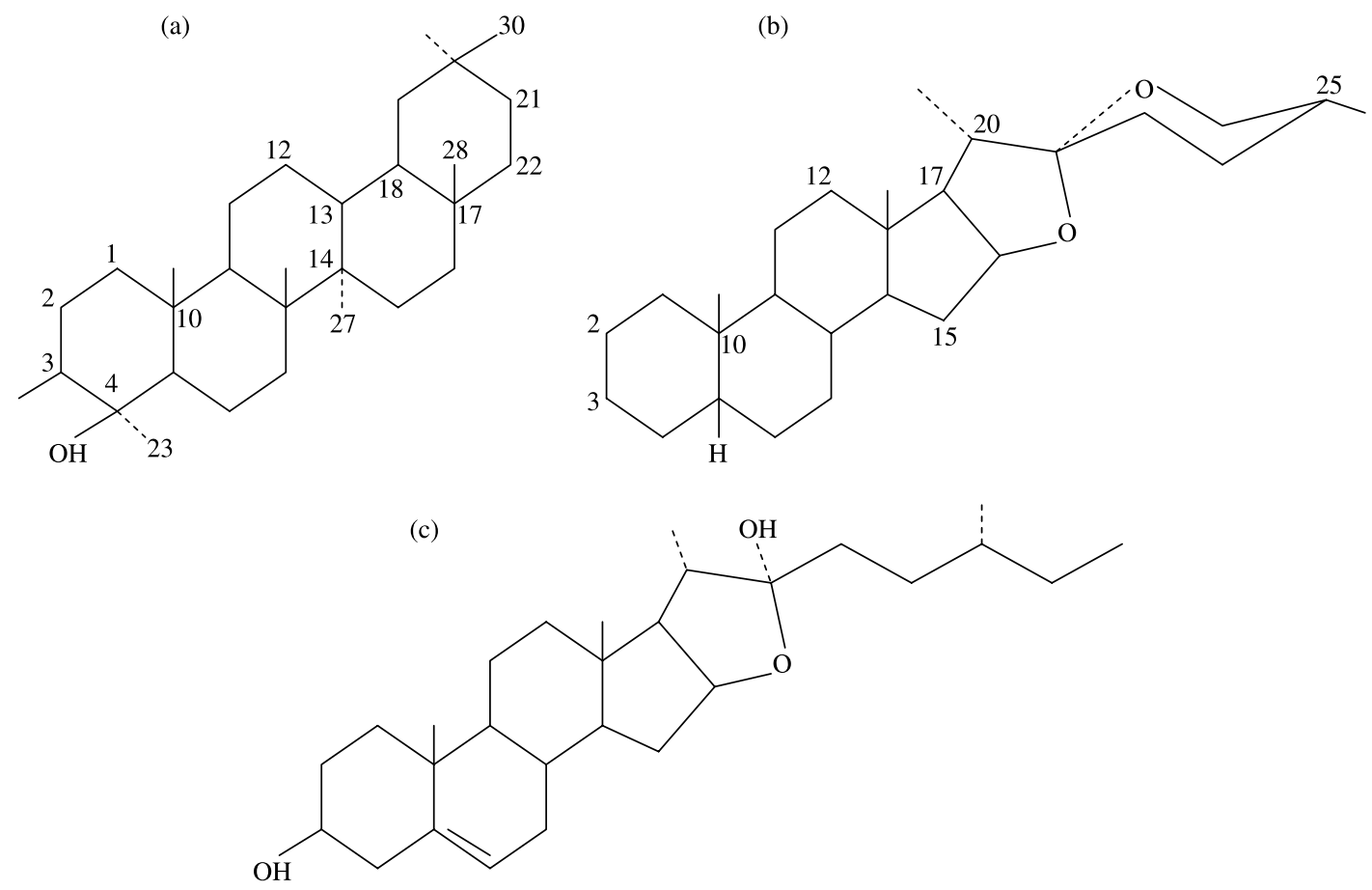

Fig. 1. Chemical structures of sapogenins: triterpenoid, for example, oleanane (a); steroids, for example, spirostanol (b) and furostanol (c). 


\begin{tabular}{|c|c|c|c|c|c|c|c|c|c|c|c|c|c|c|}
\hline Saponin type* & Animal & Dosage $(g / k g ~ D M) \dagger$ & Feed $(\mathrm{F}: \mathrm{C})$ & Prot & $\mathrm{NH}_{3}$ & TVFA & $A: P$ & Dig & MPS & Met & $\mathrm{FI}$ & $A D G$ & MY & Reference \\
\hline Biophytum petersianum & Goats & $13 \mathrm{mg} / \mathrm{kg} \mathrm{BW}$ & 70:30 & $\downarrow$ & $\downarrow$ & $\downarrow$ & $\downarrow$ & $=$ & $=$ & $x$ & $x$ & $x$ & $x$ & Santoso et al. (2007) ${ }^{(19)}$ \\
\hline B. petersianum & Goats & $26 \mathrm{mg} / \mathrm{kg} \mathrm{BW}$ & 70:30 & $\downarrow$ & $\downarrow$ & $=$ & $\downarrow$ & $\downarrow$ & $\uparrow$ & $x$ & $x$ & $x$ & $x$ & Santoso et al. (2007) \\
\hline B. petersianum & Goats & $19.5 \mathrm{mg} / \mathrm{kg} \mathrm{BW}$ & $70: 30$ & $\downarrow$ & $\downarrow$ & $\downarrow$ & $\downarrow$ & $=$ & $\uparrow$ & $x$ & $x$ & $x$ & $x$ & Santoso et al. $(2007)^{(19)}$ \\
\hline Enterolobium cyclocarpum & Sheep & $25,75 \mathrm{~g} / \mathrm{d}$ & $88: 12$ & $\downarrow$ & $x$ & $x$ & $x$ & $x$ & $x$ & $x$ & $\uparrow$ & $\uparrow \|$ & $x$ & Leng et al. (1992) ${ }^{(20)}$ \\
\hline E. cylocarpum & Sheep & $100 \mathrm{~g} / \mathrm{d}$ & 100:0 & $\uparrow$ & $\downarrow$ & $x$ & $x$ & $=\S$ & $x$ & $x$ & $\uparrow$ & $\uparrow \|$ & $x$ & Navas-Camacho et al. (1993) \\
\hline E. cylocarpum & Sheep & $300 \mathrm{~g} / \mathrm{d}$ & 100:0 & $\downarrow$ & $\downarrow$ & $x$ & $x$ & $\downarrow \S$ & $x$ & $x$ & $=$ & $\uparrow \|$ & $x$ & Navas-Camacho et al. $(1993)^{(21)}$ \\
\hline E. cylocarpum & Sheep & $200 \mathrm{~g} / \mathrm{d}$ & $60: 40$ & $\downarrow$ & $=$ & $=$ & $=$ & $x$ & $x$ & $x$ & $x$ & $x$ & $x$ & Ivan et al. (2004) (22) \\
\hline Lucerne $(27.8 \%)$ & Sheep & 10 & 100:0 & $\downarrow$ & $x$ & $=$ & $=$ & $=$ & $x$ & $=$ & $=$ & $x$ & $x$ & Klita et al. (1996) ${ }^{(17)}$ \\
\hline Lucerne $(27.8 \%)$ & Sheep & 20 to 40 & 100:0 & $\downarrow$ & $x$ & $=$ & $=$ & $\downarrow$ & $x$ & $=$ & $=$ & $x$ & $x$ & Klita et al. (1996) ${ }^{(17)}$ \\
\hline Lucerne saponins & Sheep & 20 & $60: 40$ & $\downarrow$ & $\downarrow$ & $=$ & $\downarrow$ & $=$ & $x$ & $=$ & $=$ & $x$ & $x$ & Lu \& Jorgensen $(1987)^{(18)}$ \\
\hline Lucerne saponins & Sheep & 40 & $60: 40$ & $\downarrow$ & $\downarrow$ & $\downarrow$ & $=$ & $=$ & $x$ & $\downarrow$ & $=$ & $x$ & $x$ & Lu \& Jorgensen (1987) ${ }^{(18)}$ \\
\hline Lucerne saponins & Sheep & 20 & $40: 60$ & $\downarrow$ & $=$ & $\downarrow$ & $=$ & $\uparrow$ & $x$ & $=$ & $=$ & $x$ & $x$ & Lu \& Jorgensen (1987) ${ }^{(18)}$ \\
\hline Lucerne saponins & Sheep & 40 & $40: 60$ & $\downarrow$ & $\downarrow$ & $\downarrow$ & $\uparrow$ & $\uparrow$ & $x$ & $=$ & $=$ & $x$ & $x$ & Lu \& Jorgensen $(1987)^{(18)}$ \\
\hline QS extract $(10 \%)$ & Heifers & 8 & $91: 9$ & $=$ & $=$ & $=$ & $\uparrow$ & $=$ & $=$ & $x$ & $=$ & $x$ & $x$ & Baah et al. (2007) \\
\hline QS extract $(5 \cdot 7-8 \cdot 1 \%)$ & Sheep & 13.5 & $60: 40$ & $=$ & $\downarrow$ & $\downarrow$ & $=$ & $\uparrow$ & $=$ & $=$ & $=$ & $x$ & $x$ & Pen et al. (2007) (24) \\
\hline QS plant (3\%) & Dairy cows & 10 & $51: 49$ & $=$ & $=$ & $=$ & $=$ & $=$ & $x$ & $=$ & $\uparrow$ & $=$ & $=$ & Holtshausen et al. (2009) ${ }^{(25)}$ \\
\hline Sapindus saponaria fruit & Sheep & $8 \mathrm{~g} / \mathrm{kg} \mathrm{BW}^{0.75}$ & 100:0 & $\uparrow$ & $=$ & $=$ & $\downarrow$ & $\downarrow$ & $\uparrow$ & $x$ & $\uparrow$ & $x$ & $x$ & Abreu et al. (2004) \\
\hline S. saponaria fruit $(12 \%)$ & Sheep & $5 \mathrm{~g} / \mathrm{kg} \mathrm{BW} \mathrm{B}^{0.75}$ & $67: 33$ & $\downarrow$ & $=$ & $\uparrow$ & $\downarrow$ & $\downarrow$ & $x$ & $\downarrow$ & $=$ & $\uparrow$ & $x$ & Hess et al. $(2004)^{(27)}$ \\
\hline S. saponaria pericarp & Sheep & $25 \mathrm{~g} / \mathrm{d}$ & $72: 28$ & $\downarrow$ & $=$ & $x$ & $=$ & $x$ & $x$ & $x$ & $=$ & $x$ & $x$ & Diaz et al. $(1993)^{(28)}$ \\
\hline S. saponaria pericarp & Sheep & $50 \mathrm{~g} / \mathrm{d}$ & $72: 28$ & $\downarrow$ & $\downarrow$ & $x$ & $\downarrow$ & $x$ & $x$ & $x$ & $=$ & $x$ & $x$ & Diaz et al. $(1993)^{(28)}$ \\
\hline Sarsaponins & Dairy cows & 0.077 & $40: 60$ & $x$ & $=$ & $=$ & $=$ & $=$ & $x$ & $x$ & $=$ & $=$ & $=$ & Valdez et al. (1986) ${ }^{(29)}$ \\
\hline Sarsaponins & Dairy cows & $0.2,0.41,0.62$ & $36: 64$ & $=$ & $\downarrow$ & $=$ & $=$ & $x$ & $x$ & $x$ & $=$ & $=$ & $=$ & Singer et al. $(2008)^{(30)}$ \\
\hline Sarsaponins & Calves & 0.02 & $54: 46$ & $x$ & $x$ & $x$ & $x$ & $x$ & $x$ & $x$ & $=$ & $\uparrow १$ & $x$ & Mader \& Brumm (1987) ${ }^{(31)}$ \\
\hline Sarsaponins & Sheep & $0.002,0.03$ & $50: 50$ & $=$ & $\downarrow$ & $=$ & $=$ & $=$ & $x$ & $=$ & $=$ & $x$ & $x$ & Sliwinski et al. (2002) ${ }^{(32)}$ \\
\hline Sarsaponins & Dairy cows & 0.044 & $67: 33$ & $x$ & $\times$ & $x$ & $x$ & $=$ & $x$ & $x$ & $=$ & $\hat{x}$ & $=$ & Goetsch \& Owens (1985) ${ }^{(33)}$ \\
\hline YS & Steers & 0.43 & $92: 8$ & $x$ & $x$ & $=$ & $x$ & $x$ & $\uparrow$ & $=$ & $=$ & $\uparrow$ & $\times$ & Zinn et al. $(1998)^{(34)}$ \\
\hline YS (4.4\%) & Wether & 0.24 & $85: 15$ & $x$ & $\downarrow$ & $=$ & $\downarrow$ & $x$ & $\uparrow$ & $x$ & $=$ & $x$ & $x$ & Santoso et al. (2006) ${ }^{(35)}$ \\
\hline YS extract & Dairy cows & 0.38 & $60: 40$ & $x$ & $=$ & $x$ & $x$ & $x$ & $x$ & $x$ & $=$ & $x$ & $=$ & Wilson et al. $(1998)^{(36)}$ \\
\hline YS extract & Dairy cows & 0.38 & $51: 49$ & $x$ & $=$ & $x$ & $x$ & $x$ & $x$ & $x$ & $=$ & $x$ & $=$ & Wilson et al. (1998) \\
\hline YS extract & Dairy cows & 1.46 & $63: 37$ & $x$ & $x$ & $x$ & $x$ & $=$ & $x$ & $x$ & $=$ & $x$ & $=$ & Lovett et al. (2006) \\
\hline YS extract & Dairy cows & 3.1 & $63: 37$ & $x$ & $x$ & $x$ & $x$ & $=$ & $x$ & $x$ & $\downarrow$ & $x$ & $=$ & Lovett et al. $(2006)^{(37)}$ \\
\hline YS extract & Steers & 1.25 & $63: 37$ & $\downarrow$ & $x$ & $\downarrow$ & $=$ & $=$ & $x$ & $x$ & $=$ & $x$ & $=$ & Lovett et al. $(2006)^{(37)}$ \\
\hline YS extract & Steers & 2.56 & 63:37 & $\downarrow$ & $x$ & $\downarrow$ & $=$ & $=$ & $x$ & $x$ & $=$ & $x$ & $=$ & Lovett et al. (2006) \\
\hline YS extract & Sheep & 0.13 & $75: 25$ & $x$ & $\downarrow$ & $\uparrow$ & $\downarrow$ & $=$ & $x$ & $\downarrow$ & $=$ & $x$ & $x$ & Wang et al. $(2009)^{(38)}$ \\
\hline YS extract & Sheep & 0.12 & $70: 30$ & $x$ & $\downarrow$ & $=$ & $=$ & $=$ & $=$ & $\downarrow$ & $=$ & $x$ & $x$ & Santoso et al. $(2004)^{(39)}$ \\
\hline YS extract & Dairy cows & 0.07 & $48: 52$ & $x$ & $x$ & $x$ & $x$ & $=$ & $=$ & $x$ & $\downarrow$ & $x$ & $x$ & Wu et al. (1994) \\
\hline YS extract & Dairy cows & 0.06 & 48:52; urea added & $x$ & $x$ & $x$ & $x$ & $=$ & $=$ & $x$ & $\uparrow$ & $x$ & $x$ & Wu et al. $(1994)^{(40)}$ \\
\hline YS extract & Dairy cows & 0.03 to 0.12 & $38: 62$ & $x$ & $=$ & $=$ & $=$ & $x$ & $x$ & $x$ & $=$ & $x$ & $x$ & Wu et al. $(1994)^{(40)}$ \\
\hline YS extract & Steers & 0.075 & $92: 8$ & $x$ & $=$ & $=$ & $=$ & $x$ & $x$ & $x$ & $=$ & $x$ & $x$ & Hussain \& Cleeke (1995) ${ }^{(41)}$ \\
\hline YS extract & Steers & 0.075 & $96: 4$ & $x$ & $=$ & $=$ & $=$ & $x$ & $x$ & $x$ & $=$ & $x$ & $x$ & Hussain \& Cleeke (1995) ${ }^{(41)}$ \\
\hline YS extract & Steers & 0.075 & 45:55 & $x$ & $=$ & $=$ & $=$ & $\hat{x}$ & $x$ & $x$ & $=$ & $\hat{=}$ & $x$ & Hussain \& Cleeke (1995) ${ }^{(41)}$ \\
\hline YS extract & Steers & 0.075 & $48: 52$ & $x$ & $=$ & $=$ & $=$ & $x$ & $x$ & $x$ & $=$ & $=$ & $x$ & Hussain \& Cleeke (1995) \\
\hline YS extract (10\%) & Dairy cows & 2.8 & $40: 60$ & $=$ & $=$ & $=$ & $=$ & $=$ & $x$ & $x$ & $=$ & $x$ & $=$ & Benchaar et al. $(2008)^{(42)}$ \\
\hline YS extract $(9.6-11.7 \%)$ & Sheep & 13.8 & $60: 40$ & $=$ & $\downarrow$ & $\downarrow$ & $=$ & $=$ & $=$ & $=$ & $=$ & $x$ & $x$ & Pen et al. (2007) \\
\hline YS plant (4.4\%) & Heifers & 1.96 & $61: 39$ & $\downarrow$ & $=$ & $=$ & $\downarrow$ & $=$ & $=$ & $x$ & $=$ & $x$ & $x$ & Hristov et al. (1999) ${ }^{(43)}$ \\
\hline YS plant $(4.4 \%)$ & Heifers & 5.83 & $61: 39$ & $\downarrow$ & $\downarrow$ & $=$ & $\downarrow$ & $=$ & $=$ & $x$ & $=$ & $x$ & $x$ & Hristov et al. (1999) ${ }^{(43)}$ \\
\hline YS plant $(6 \%)$ & Dairy cows & 10 & $51: 49$ & $=$ & $\downarrow$ & $=$ & $=$ & $=$ & $x$ & $=$ & $\uparrow$ & $=$ & $=$ & Holtshausen et al. (2009) ${ }^{(25)}$ \\
\hline
\end{tabular}

$\mathrm{F}: \mathrm{C}$, forage:concentrate ratio in diet; Prot, protozoal numbers; $\mathrm{NH}_{3}$, ammonia concentration; TVFA, total volatile fatty acid concentration; A:P, acetate:propionate ratio; Dig, digestibility of fibre components; MPS, efficiency of microbial protein synthesis; Met, methane; FI, DM intake; ADG, average daily gain; MY, milk yield; BW, body weight; $\downarrow$, decrease; $\times$, not reported; = , no effect; $\uparrow$, increase; QS, Quillaja saponaria; YS, Yucca schidigera.

† Dose is given as $\mathrm{g} / \mathrm{kg}$ diet unless otherwise stated, and was calculated as $\mathrm{g} / \mathrm{kg}$ from feed intake and inclusion of saponin products whenever possible. $\ddagger$ Effect is relative to control.

$\S$ DM digestibility.

ๆ $A D G$ was greater at 0 to $28 \mathrm{~d}$ of feeding, after which there was no effect. 
Probably all types of saponins inhibit protozoal activity depending upon the concentrations in the diet. Lucerne saponins (triterpene saponins), isolated by ethanol extraction and partial acid hydrolysis, caused a decrease in protozoal numbers in the rumen of sheep by 34 and $66 \%$ at high concentrations of 2 and $4 \%$ of dietary DM, respectively ${ }^{(18)}$. A methanol extract of Sapindus rarak fruit also depressed the protozoal population in the rumen of sheep by $57 \%$, which was attributed to the presence of saponins in the extract ${ }^{(48)}$. Saponin-like material in the organic phase of a butanol-water mixture of Sesbania sesban foliage (containing oleanane-type triterpene saponins), a leguminous tree, was found to be inhibitory to protozoal activity ${ }^{(49)}$. Similarly, the saponins from Q. saponaria and Acacia auriculiformis ${ }^{(46)}$, theasaponins ${ }^{(50,51)}$ and Sapindus saponaria ${ }^{(52)}$ have also shown an anti-protozoal activity in vitro. Monforte-Briceno et al. ${ }^{(53)}$ also reported defaunating effects of saponins present in Enterolobium cyclocarpum and Acacia angustissima. However, there is some evidence that saponins do not influence protozoal numbers in vitro (44 to $176 \mathrm{mg}$ Yucca saponins and 100 to $400 \mathrm{mg}$ Quillaja saponins per litre medium $^{(47)} ; 1$ to $100 \mathrm{mg} / \mathrm{kg}$ DM substrate $\left.{ }^{(32)}\right)$, and in sheep (1180 to $1477 \mathrm{mg}$ Yucca or Quillaja saponins/kg DM intake $^{(24)}$, dairy cows (60 g Yucca extract (10\% saponins) per d with feed intake of $21.8 \mathrm{~kg}$, i.e. $275 \mathrm{mg}$ Yucca saponins/kg DM intake) ${ }^{(42)}$ and heifers (8 g Quillaja extract (10\% saponins) per $\mathrm{kg} \mathrm{DM}$ intake, i.e. $800 \mathrm{mg}$ Quillaja saponins $/ \mathrm{kg}$ DM intake $)^{(23)}$. The inefficacy of the saponins to cause protozoal inhibition in these studies is not clearly known. The lack of anti-protozoal effect of the saponins might involve the use of low doses of saponins in some studies, and an adaptation of rumen microbes to saponins in other studies.

The methods of extraction of saponins from plant materials may show different anti-protozoal activity. For example, Patra et al. ${ }^{\left({ }^{10)}\right.}$ noted that a methanol extract of pods of Acacia concinna exhibited stronger activity against protozoa than water and ethanol extracts. Similarly, Agarwal et al. ${ }^{(54)}$ noted that methanol, ethanol and water extracts of berries of Sapindus mukorossi inhibited protozoal numbers in an in vitro gas production system and methanol extract was more active that water and ethanol extracts. The dose-dependent effect of the saponins on protozoa has clearly been observed in many studies $^{(10,19,54,55)}$. The oral administration of saponins from the plant Biophytum petersianum decreased protozoal numbers in goats by 35 and $40 \%$ at the dose of 13 and $19.5 \mathrm{mg} / \mathrm{kg}$ body weight, respectively, beyond which protozoal counts did not further reduce ${ }^{(19)}$. Similarly, Pen et al. ${ }^{(55)}$ reported that commercial extracts of $Y$. schidigera (9\% saponins; monodesmosidal steroid) and $Q$. saponaria (6\% saponins; bidesmosidal triterpene) decreased protozoal numbers linearly with increasing doses of both the extracts $(0,2,4$ and $6 \mathrm{ml} / \mathrm{l}$ of in vitro medium). From the studies of Santoso et al. ${ }^{(19)}$ and Pen et al. ${ }^{(55)}$, it could be noted that the inhibition of protozoal counts plateaued at a certain dose specific for saponin type (for example, decreased protozoal numbers of $53 \%$ for Yucca, $29 \%$ for Quillaja and $40 \%$ for Biophytum petersianum), beyond which there was no appreciable inhibition of protozoa. Therefore, it appears that all of the protozoal species are not equally susceptible to the toxic effect of saponins, indicating that the range of activity of saponins might be dependent upon the type of saponins and protozoal species. Because the concentrations of saponins in Yucca (9\% saponins) and Quillaja (6\% saponins) extracts were different in the study of Pen et $a l .{ }^{(55)}$, after adjusting the concentration of saponins (i.e. $4 \mathrm{ml}$ Yucca equivalent to $6 \mathrm{ml}$ Quillaja extract) in the medium, it was noted that Yucca extract (53\% reduction of total protozoa compared with control) strongly inhibited the protozoal growth compared with Quillaja extract (29\% reduction of total protozoa compared with control). It could be tested whether a mixture of the saponins of different types might show a synergistic anti-protozoal activity. It has been noted that the degree of toxicity of saponins to rumen protozoa greatly differs in different accessions of the same plant, for example, Sesbania sesban ${ }^{(56)}$. This would suggest the presence of different types and/or concentrations of saponins in different accessions of plants. Additionally, the effects of saponins on ruminal protozoa could be dietdependent. For example, Hess et al. ${ }^{(57)}$ reported that protozoa numbers were decreased by saponin-containing Sapindus saponaria fruits only when added to a diet supplemented with a high-quality legume (Arachis pintoi), but not with Cratylia argentea, a medium-quality legume. Conversely, anti-protozoal effects of lucerne saponins did not show a diet $\times$ saponin interaction, although inhibition was greater for concentrate- $(75 \%)$ than roughage- $(47 \%)$ based diets at $4 \%$ saponin inclusion ${ }^{(18)}$. The composition of the diet has a strong influence on the protozoal community ${ }^{(58)}$. Therefore, a diet-dependent effect might arise from the selectivity of saponins to protozoal species. However, no information is available on the effect of saponins on the species of rumen protozoa. Ivan et al. ${ }^{(22)}$ reported that saponins of Enterolobium cyclocarpum reduced the protozoal numbers without changing the protozoal generic composition in sheep. Benchaar et al. ${ }^{(42)}$ observed no effect of saponins on total protozoal counts as well as generic composition.

\section{Bacteria and fungi}

Relatively few studies have addressed the effects of saponins on pure cultures of rumen micro-organisms. Wallace et al. ${ }^{(44)}$ showed that $Y$. schidigera extract $(1 \%$, $\mathrm{v} / \mathrm{v}$ ) inhibited the growth of pure cultures of Butyrivibrio fibrisolvens and Streptococcus bovis, while the growth of Prevotella ruminicola was stimulated and the growth of Selenomonas ruminantium was unaffected by Yucca extract. In another experiment, Yисса saponins inhibited the growth of Streptococcus bovis, Prevotella bryantii and Ruminobacter amylophilus by causing the alteration of the cell wall of the bacteria, while enhancing the growth of Selenomonas ruminantium ${ }^{(59)}$. Among the primary cellulolytic bacteria, the activity of Fibrobacter succinogenes was unaffected, but the cellulose-digesting ability of Ruminococcus albus and Ruminococcus flavefaciens was markedly reduced by Yucca saponins ${ }^{(59)}$. These studies clearly suggest species-dependent effects of saponins on rumen bacteria, which might offer a selective manipulation of rumen metabolism. For example, saponins included in 
high concentrate-based diets may reduce the incidence of acidosis by inhibiting the growth of Streptococcus bovis, the numbers of which normally rapidly increase with concentrate-based diets, fermenting the soluble starch to lactate ${ }^{(60)}$. The reason for the growth-promoting effect of saponins on some pure cultures of bacteria is unclear. However, it is possible that low doses of saponins might increase the permeability of the cell membrane in a controlled manner, thus allowing the increased absorption of nutrients into the bacterial cells ${ }^{(61)}$. In studies with mixed rumen microbial population, saponin-containing plants increased bacterial numbers, presumably as a consequence of inhibition of protozoal numbers ${ }^{(27-29,48,49)}$. The study of Hess et al. ${ }^{(27)}$ showed that supplementation with fruits of Sapindus saponaria, which supplied crude saponins at $0.6 \mathrm{~g} / \mathrm{kg}$ body weight $^{075}$, increased total bacterial numbers, and decreased total ciliate protozoa count in lambs fed basal diets of grass hay or grass and legume mixture (1:2 or $2: 1)$ along with concentrate (1:3). Cellulolytic bacterial counts have been shown to increase due to the feeding of Enterolobium cyclocarpum containing saponins ${ }^{(28)}$ and an extract of Sapindus rarak ${ }^{(48)}$. In a species-level study of cellulolytic bacteria, Muetzel et al. ${ }^{\text {(62) }}$ found that the addition of saponin-containing Sesbania pachycarpa leaves did not affect the growth of $F$. succinogenes and Ruminococcus flavefaciens, but inhibited the growth of Ruminococcus albus in vitro. Another type of saponin, theasaponin (an oleanene-type triterpene) markedly (79\%) decreased the population density of rumen fungi; however, the numbers of $F$. succinogenes increased $(41 \%)$ and Ruminococcus flavefaciens were not affected by theasaponins at a concentration of $400 \mathrm{mg} / \mathrm{l}$ culture medium as quantified by real-time $\mathrm{PCR}^{(51)}$.

Ruminal fungi, Neocallimastix frontalis and Piromyces rhizinflata, were also sensitive to $Y$. schidigera saponins ${ }^{(59)}$. However, fungal numbers increased when sheep were fed with diets containing Sapindus saponaria ${ }^{(28)}$ or Enterolobium cyclocarpum ${ }^{(21)}$. Wina et al. ${ }^{(63)}$ noted that at low concentrations of Sapindus rarak saponins had a positive effect on Chytridiomycetes, a rumen fungus, during the long-term feeding, while no effect was observed with higher concentrations in sheep. These studies illustrate that a positive effect of saponins on rumen fungi might be obtained perhaps at low doses. Wina et al. ${ }^{(64)}$ investigated the effect of saponins from a methanol extract of Sapindus rarak at concentrations of $0,0.25,0.5,1.0,2.0$ and $4.0 \mathrm{mg} / \mathrm{ml}$ to an elephant grass and wheat bran $(7: 3$, w/w) diet in vitro. The microbial biomass gradually increased with increasing doses of extract from $102.8 \mathrm{mg} / \mathrm{g}$ substrate incubated (control) to $147.3 \mathrm{mg} / \mathrm{g}$ substrate incubated at $4 \mathrm{mg} / \mathrm{ml}$ and the total protozoal counts decreased. Studies with membrane hybridisation (a molecular method to quantify rRNA of micro-organisms) also showed no eukaryotic RNA in the presence of the extract at concentrations greater than $1 \mathrm{mg} / \mathrm{ml}$. The bacterial RNA concentration increased only at $1 \mathrm{mg} / \mathrm{ml}$ compared with the control. There was no effect on Fibrobacter spp.; however, there was a negative effect on Ruminococcus albus and Ruminococcus flavefaciens at 2 and $4 \mathrm{mg} / \mathrm{ml}$ of extract. The growth of Chytridiomycetes was reduced at the highest concentration. The in vivo trials with sheep and goats fed a saponin extract of Sapindus rarak up to 0.72 and $0.60 \mathrm{~g} / \mathrm{kg}$ body weight, respectively, also confirmed that Fibrobacter spp. were not affected by the Sapindus rarak extract, while Ruminococcus albus, Ruminococcus flavefaciens and Chytridiomycetes showed a short-term negative effect to the application of saponins, but were not affected when this extract was fed for a longer period $(105 \mathrm{~d})^{(63)}$. From the studies of Wang et al. ${ }^{(59)}$, Muetzel et al. ${ }^{(62)}$, Wina et al. ${ }^{(63,64)}$ and Guo et al. ${ }^{(51)}$, it is clear that $F$. succinogenes is relatively resistant to saponins compared with other cellulolytic bacterial species. The presence of 2-aminoethylphosphonic acid in its cell wall may enhance the membrane stability of Fibrobacter spp. ${ }^{(65)}$, which might explain the insensitivity of saponins to this bacterium. 2-Aminoethylphosphonic acid covalently linked to membrane polymers renders the membrane resistant to enzymic hydrolysis, which may promote the longevity of the organisms ${ }^{(65,66)}$.

\section{Rumen archaea}

There has been little experimentation demonstrating the direct effect of saponins on rumen archaea, but the direct effect cannot be ruled out. The studies on pure cultures of rumen methanogens are scant. The reduction of methane production by Sapindus saponaria was observed in a defaunated state without any change in methanogen counts, indicating that saponins may directly influence the activity of methanogens ${ }^{(67)}$. Guo et al. ${ }^{(51)}$ noted that tea saponins $(400 \mathrm{mg} / \mathrm{l})$ had no effect on the growth and expression of the methyl coenzyme $\mathrm{M}$ reductase subunit A gene ( $m c r A)$ of Methanobrevibacter ruminantium. In mixed ruminal cultures, tea saponins also did not affect total archaeal numbers, but the activity of the $m c r A$ gene decreased markedly $(76 \%)$ and methane production lowered by $8 \%{ }^{(51)}$. Saponins from Sapindus rarak decreased the methanogen RNA concentration at a dose of $4 \mathrm{mg} / \mathrm{ml}$ of in vitro medium, while lower concentrations $(<4 \mathrm{mg} / \mathrm{ml})$ had no effect on methanogens ${ }^{(64)}$. The study of Wina et al. ${ }^{(64)}$ did not confirm that a decrease in methanogen RNA concentration is due to direct inhibition by saponins, but did suggest it may also result from the inhibition of protozoa activity. However, it has also been reported that saponins of Sapindus saponaria fruits increased the methanogen population in sheep although methane production reduced $^{(27)}$. The reason for the increase in the methanogen population was not clear in this study.

\section{Explaining the effects of saponins on micro-organisms}

A schematic illustration of effects of saponins on rumen microbes and fermentation is presented in Fig. 2. The modifications of rumen fermentation by saponins are mediated via a direct influence on the composition and the activity of rumen protozoa, bacteria, fungi and archaea. The general mode of action of saponins on microorganisms is their interaction with the sterol moiety ${ }^{(15)}$, which is present in the membrane of protozoa ${ }^{(58)}$. Thus, an anti-protozoal activity of saponins may be due to the destruction of protozoal cell membranes, causing leaking of cell contents. It has been reported that the main sterols present in entodiniomorphs are stigmastanol, campestanol 


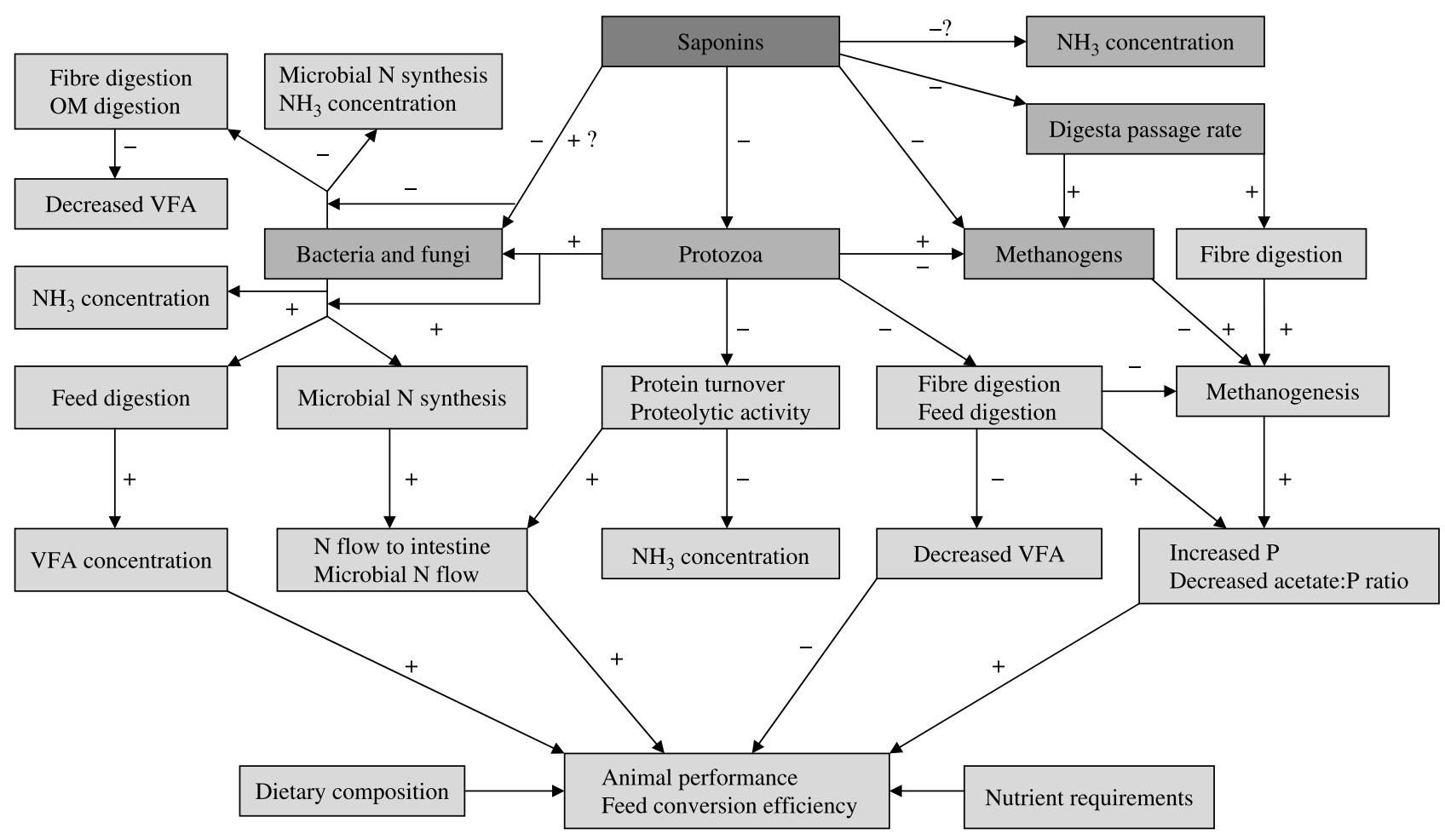

Fig. 2. A schematic presentation of the proposed effects of saponins on rumen microbes and fermentation. Primary effects modify the composition of rumen microbes and secondary effects modify the rumen fermentation. +, Increase; - , decrease; OM, organic matter; VFA, volatile fatty acids; $\mathrm{P}$, propionate.

and cholestanol, whereas the major sterol in holotrichs is cholestanol $^{(68)}$. The different composition of sterols in rumen protozoa may relate to the different sensitivity of protozoa to saponins. Several factors such as saponin structure, dose level, adaptation process, diet composition and microbial community structure influence the effect of saponins on the rumen microbial population (Fig. 3). The structures of saponins and their varying proportions

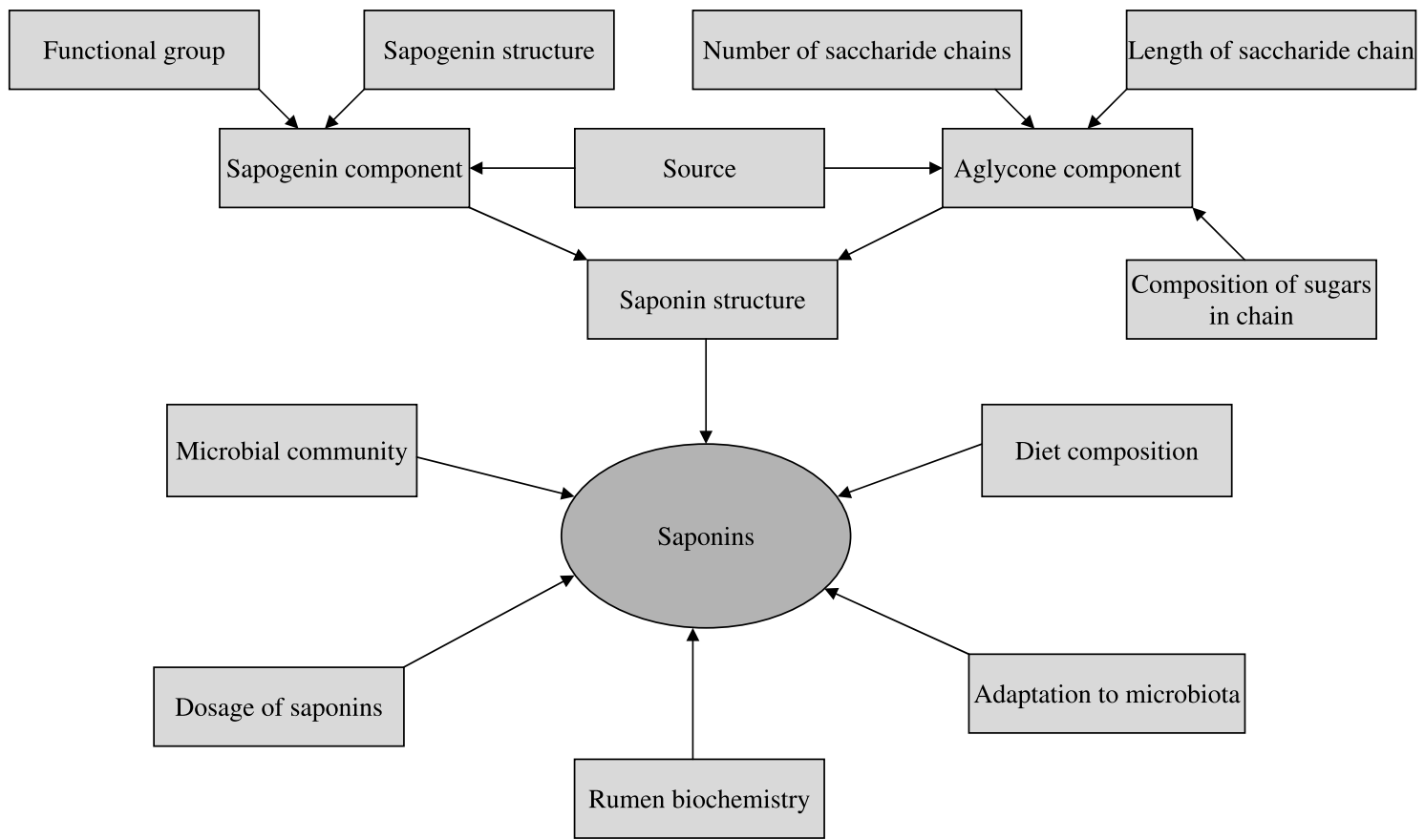

Fig. 3. A schematic presentation of factors affecting the effects of saponins on rumen microbes. 
from different sources of the same plant material may elicit different responses on rumen metabolism. Also the method of saponin estimation in the extract or plant may differ $^{(12)}$, which may explain the differences in response of saponins despite similar dose levels ${ }^{(25)}$. For example, Hostettmann \& Marston ${ }^{(15)}$ discussed that spectrophotometric methods are very sensitive, but not suitable for estimation of saponins in crude plant extracts, since colour reactions are not specific, and coloured products may form with phytosterols and flavonoids extracted with saponins. Klita et al. ${ }^{(17)}$ mentioned that concentrations of saponins determined by HPLC procedures are commonly lower than those determined by biological procedures (for example, haemolytic micro-method). Additionally, saponins may not be completely extracted from vegetable materials ${ }^{(15)}$.

The responses of rumen bacteria and fungi to saponins may be mediated through defaunation and/or direct effects. An increase in the number of bacteria and fungi due to the addition of saponins has been observed in some studies, which is believed to be as a consequence of reduced engulfment of these micro-organisms by protozoa ${ }^{(58)}$. The microbial growth in the rumen is also affected by the presence of saponins, which may decrease the bacterial and fungal numbers. Therefore, the observed effect of saponins on rumen microbes is the balance between anti-protozoal effects (hence increased microbial growth) and direct antibacterial effects of saponins. The antibacterial effects of saponins may be mediated by disrupting the cell membranes, rather than simply altering the surface tension of the extracellular medium ${ }^{(5,61)}$. Both Gram-positive and Gram-negative bacteria are sensitive ${ }^{(69)}$, although their sensitivity depends upon the structure of the aglycone moiety of saponins ${ }^{(70)}$ and the fatty acid composition of cell membranes of target bacteria. For instance, Wallace et al. ${ }^{(44)}$ concluded from their study that Gram-positive bacteria were more susceptible compared with Gram-negative bacteria in the presence of Yucca saponins. Later, Wang et al. ${ }^{(59)}$ reported that Yucca saponins inhibited pure cultures of rumen cellulolytic bacteria and fungi, but their effects on amylolytic bacteria varied among species. Similarly, Gramnegative bacteria were negatively affected by saponins extracted from the leaves of Gymnema sylvestre and Eclipta prostrata $^{(71)}$, whereas the effect of medicagenic acid, a lucerne saponin, was more pronounced against Grampositive bacteria ${ }^{(70)}$. Although the addition of sugar units decreases the antimicrobial properties ${ }^{(70)}$, the sugar moiety may not be important for activity in the rumen, as the side chain of sugars might be rapidly degraded by the mixed rumen microbial cultures ${ }^{(72)}$. From this perspective, the sapogenin structure-activity relationship of saponins with greater anti-protozoal properties and weak antibacterial (for example, rumen cellulolytic bacterial populations) and fungal activity could be targeted for rumen micro-organisms for improvement of fermentation. Further, $\mathrm{Li}$ et al. ${ }^{(73)}$ demonstrated that tea saponins (triterpenoid type) showed better antimicrobial activity at low $\mathrm{pH}$ in vitro. This indicates that the effect of saponins may be modulated by the $\mathrm{pH}$ in the rumen depending upon the concentrate- and roughage-based diets. The method of preparation and purification might also give rise to different responses to saponins. For example, Sen et al. ${ }^{(61)}$ noted that Quillaja saponins from different commercial sources showed maximum effects on growth of Escherichia coli at different concentrations of saponins in the medium.

The major mechanism suggested for the antifungal activity of saponins is their interaction with sterols ${ }^{(11)}$, followed by pore formation and loss of membrane integrity. Some saponins may show a specific inhibitory activity to fungi but not to bacteria. For example, saponins isolated from Allium minutiflorum exhibited an antifungal activity depending upon the concentration and type of saponins, but did not show an appreciable antibacterial activity in the non-rumen bacteria ${ }^{(7)}$. From the perspective of structureactivity relationships, saponins with the triterpene or spirostanol moiety generally demonstrate stronger antifungal activities, whereas furostanol saponins with bidesmosidic nature show little to no bacteriostatic and fungicidal effects ${ }^{(75)}$. The antifungal activity of these steroidal saponins is also associated with their individual steroidal sapogenins as well as the number and structure of monosaccharide units in their sugar chains. It has been demonstrated that diosgenin saponins with triglycosides were active against Candida albicans and Candida glabrata, while the monoglycoside and diglycoside did not show any activity ${ }^{(76)}$.

\section{Microbial adaptation and metabolism of saponins}

One of the challenges of using saponins or saponincontaining plants is that the anti-protozoal activity is transient ${ }^{(49,56)}$. After feeding of Sesbania sesban for $10 \mathrm{~d}^{(49)}$ and Enterolobium cyclocarpum for $14 \mathrm{~d}^{(22)}$, the antiprotozoal activity of saponins present in these plants was not observed in sheep. Teferedegne ${ }^{(77)}$ also noted a timedependent detoxification process of the saponins in ruminal fluid in vitro. The study of Newbold et al. ${ }^{(49)}$ suggested that protozoa per se did not become resistant to these antiprotozoal compounds, but rather the rumen bacterial population degraded the saponins ${ }^{(49,56)}$. However, antiprotozoal activities of the saponins from Yucca fed for $17 \mathrm{~d}^{(43)}$ and Sapindus rarak fed for 3 months ${ }^{(63)}$ were observed in the presence of mixed rumen microbial populations in the rumen. The study of Wina et al. ${ }^{(63)}$ showed that a negative effect of saponins from Sapindus rarak on Ruminococcus albus, Ruminococcus flavefaciens and Chytridiomycetes for a short period, but this effect disappeared after a long period of feeding. From the study of Wina et al. ${ }^{(63)}$, it was also apparent that protozoal populations were not affected by Sapindus saponaria saponins on day 13 in goats, probably due to detoxification of saponins by microbes. However, anti-protozoal properties of these saponins were persistent up to 3 months in sheep, indicating probable previous exposure of the goats to saponins.

The metabolism of saponins in the rumen involves deglycosylation ${ }^{(45,59)}$ and structural changes of the aglycone nucleus ${ }^{(45)}$. There appears to be no evidence of cleavage of ring structures of steroidal or triterpene cores of saponins by rumen anaerobic or even non-rumen anaerobic and aerobic micro-organisms. Saponins are degraded in batch cultures of rumen fluid in vitro ${ }^{(72)}$ to sapogenins, the aglycone remaining after the removal of the sugar moiety. Thereafter, 
the resultant sapogenins undergo structural changes (oxidation and reduction) more slowly ${ }^{(45)}$. Wang et al. ${ }^{(59)}$ suggested that $F$. succinogenes apparently deglycosylated the saponins from $Y$. schidigera. Further, an increase in the thickness of the cell wall of Prevotella bryantii was noted when these bacteria were grown in the presence of Yucca saponins, indicating an adaptation to saponins ${ }^{(59)}$. The observation made by Odenyo et al. ${ }^{(78)}$ that Sesbania sesban introduced directly into the rumen remained toxic to protozoa, but not dietary Sesbania sesban, implies that chewing might have caused the detoxification, perhaps by salivary amylase, or that the larger particle size protected saponins from degradation.

Lucerne saponins were degraded by $96-98 \%$ in the total digestive tract of sheep ${ }^{(79)}$. Similarly, white clover saponins were not detectable in the residue of white clover (Trifolium repens) incubated in the rumen by nylon bags for $24 \mathrm{~h}^{(80)}$ and mowrin, saponins from mahua (Bassia latifolia) seeds, was degraded by $46 \%$ after $24 \mathrm{~h}$ of incubation in vitro ${ }^{(81)}$. Makkar \& Becker ${ }^{(72)}$ observed that Quillaja saponins were degraded $100 \%$ in an in vitro medium containing rumen fluid of cows after $24 \mathrm{~h}$ of incubation, while no degradation was observed up to $6 \mathrm{~h}$ of incubation. Meagher et al. ${ }^{(82)}$ investigated the metabolism of diosgenin-derived saponins in the gastrointestinal tract of sheep. In the rumen, saponins underwent rapid hydrolysis to afford free sapogenins, and then part of these free sapogenins underwent oxidation and reduction into epismilagenin, smilagenone, smilagenin and tigogenin. In the duodenum, jejunum and ileum, these products were absorbed and then secreted through the bile as conjugated and free sapogenins. The epimerisation of sapogenins was continued in the caecum and colon. A similar phenomenon of metabolism of saponins from Narthecium ossifragum and Y. schidigera (both plants contain predominantly sarsapogenin and smilagenin aglycone moieties) was observed by Flaoyen $\&$ Wilkins ${ }^{(83)}$ and Flaoyen et al. ${ }^{(84,85)}$ in sheep. Collectively, these studies suggest that the rate and extent of degradation of different saponins in the rumen varies greatly, which indicates that some saponins might be effective for long periods.

\section{Effects of saponins on rumen fermentation}

\section{Nitrogen metabolism}

A number of studies have reported that saponins or saponincontaining plants decreased rumen ammonia $\mathrm{N}$ concentrations in vitro ${ }^{(25,44,50,86-88)}$ and in vivo ${ }^{(24,39,41,43,46)}$. The effect of saponins in reducing rumen ammonia concentrations was more pronounced for Yucca extract compared with Quillaja extract ${ }^{(25,55)}$, probably due to strong anti-protozoal properties of Yucca compared with Quillaja saponins. However, saponins do not always reduce rumen ammonia concentrations. Sapindus saponaria ${ }^{(27)}$ and Yucca extract $^{(42)}$ included in concentrate diets did not significantly reduce rumen ammonia concentrations, although it should be noted that the Yucca extract did not affect rumen protozoal numbers either. In studies with dairy cows, inclusion of sarsaponins up to 77 parts per million (ppm) of $\operatorname{diet}^{(29,33)}, 9 \mathrm{~g} / \mathrm{d}^{(36)}, 8 \mathrm{~g} / \mathrm{d}^{(40)}$ and $10 \mathrm{~g}$ of Yucca whole plant (equivalent to $0.6 \mathrm{~g}$ saponins/kg DM) or $10 \mathrm{~g}$ Quillaja whole plant (equivalent to $0 \cdot 3 \mathrm{~g}$ saponins $/ \mathrm{kg} \mathrm{DM})^{(25)} \mathrm{did}$ not influence ammonia concentrations in the rumen, probably due to low concentrations of saponins inclusion in the diets. Valdez et al. ${ }^{(29)}$ and Hess et al. ${ }^{(27)}$ have reported that by decreasing protozoal numbers slightly, saponins increased bacterial numbers, which may explain why saponin treatments are not always associated with reduced rumen ammonia concentrations.

Yucca, Quillaja and Acacia saponins have been shown to increase the efficiency of microbial protein synthesis in an in vitro fermentation system containing hay as a substrate ${ }^{(46)}$. Saponins in higher concentrations generally have adverse effects on microbial protein synthesis subject to saponin types. Yucca saponins increased microbial protein synthesis at $15 \mathrm{mg} / \mathrm{l}$ medium, but decreased it at higher concentrations ${ }^{(86)}$, whereas tea saponins increased microbial protein synthesis up to a concentration of $267 \mathrm{mg} / \mathrm{l}^{(50)}$. The greater bacterial protein synthesis, which could be the result of the prevention of predation of bacteria by protozoa, may overwhelm the decreased protozoal growth, and thus overall microbial protein synthesis could increase due to the administration of saponins. Therefore, saponin-specific doses needed for anti-protozoal effects, but with minimum inhibitory effects on bacteria and fungi, need to be established. In an animal feeding trial, Santoso et al. ${ }^{(35)}$ reported that daily supplementation of a basal diet consisting of timothy silage and a concentrate (85:15 on a DM basis) with 240 ppm of Yucca saponins reduced rumen ammonia $\mathrm{N}$ concentrations in sheep. The microbial $\mathrm{N}$ supply and efficiency of microbial $\mathrm{N}$ synthesis were greater in sheep fed with Yucca diets $v$. those fed with control diets. In another experiment, Santoso et al. ${ }^{(19)}$ reported that oral administration of saponins $(0,13,19.5$ and $26 \mathrm{mg} / \mathrm{kg}$ body weight) from Biophytum petersianum linearly decreased ruminal ammonia $\mathrm{N}$ concentrations, urinary $\mathrm{N}$ and total $\mathrm{N}$ excretion, and increased retained $\mathrm{N}$ as a proportion of $\mathrm{N}$ digested, efficiency of microbial $\mathrm{N}$ synthesis and microbial $\mathrm{N}$ supply in goats fed a diet consisting of elephant grass silage and concentrate (70:30). Klita et al. ${ }^{(17)}$ reported that total $\mathrm{N}$ flow to the duodenum increased in sheep fed a saponin extract of lucerne root up to $4 \%$ of DM intake. However, in studies with cattle receiving $Y$. schidigera saponins, a decrease in the efficiency of microbial protein synthesis was observed, probably due to the suppression of bacterial and protozoal growth ${ }^{(33)}$. A diet-dependent response to saponins on bacterial protein synthesis has been clearly observed by Lu \& Jorgensen ${ }^{(18)}$, who noted that efficiency of bacterial protein synthesis and bacterial protein flow to the duodenum were decreased by lucerne saponins in a roughage-based diet, but had no effect in a concentrate-based diet.

\section{Digestion of feeds and volatile fatty acid production}

Mixed effects of saponins on feed digestion are reported in the literature. Saponins from Sapindus saponaria ${ }^{(57)}$, Yucca and Quillaja ${ }^{(25)}$ plants reduced the digestibility of fibre components in vitro. Similarly, lucerne saponins (up to $4 \%$ of DM intake) linearly decreased both ruminal and total tract digestibilities of organic matter, fibre components and digestibility in sheep fed a grass hay diet ${ }^{(17)}$. The xylanase 
activity and neutral-detergent fibre digestibility decreased at higher levels of Sapindus rarak extract ${ }^{(64)}$. The digestibilities of organic matter and neutral-detergent fibre also reduced in the presence of Sapindus saponaria fruits ${ }^{(27)}$ and extracts of Sapindus mukorossi ${ }^{(54)}$. In many other studies $^{(21,24,27,37,38)}$, saponins have been reported not to influence nutrient digestibilities. A number of studies have reported increases in digestibilities of organic matter and fibre components. Goetsch \& Owens ${ }^{(33)}$ reported a significant increase in the digestibility of organic matter in cattle fed $44 \mathrm{ppm}$ of Yucca saponins. Valdez et al. ${ }^{(29)}$ recorded an increased digestibility of organic matter, together with a tendency toward an increased digestibility of acid-detergent fibre with increasing application levels of Yucca extract (up to $77 \mathrm{ppm}$ ). Pen et al. ${ }^{(24)}$ reported an increase in neutral-detergent fibre digestibility by sheep supplemented with Quillaja saponins. Similarly, the total tract digestibilities of organic matter and fibre were increased by lucerne saponins in a concentrate-based diet for sheep ${ }^{(18)}$. Saponins might change the site of digestion in the digestive tract. For example, in the latter experiment, the degradability of cellulose in the rumen was depressed by added saponins, but the degradability of fibre fractions in the hindgut was greatly increased.

There are varying reports on the effects of saponins on ruminal volatile fatty acid (VFA) concentrations, as digestibility of feeds varied among the studies. No difference in total VFA concentrations with the supplementation of saponins ${ }^{(17,24,25,39,43,51,55)}$ have been reported. However, reductions in VFA concentration due to supplementation of lucerne saponins at $4 \%$ of DM intake ${ }^{(18)}$ and Yucca extract at levels of 25 and $50 \mathrm{~g} / \mathrm{d}$ to Holstein cows $^{(37)}$ have also been reported. Saponins in higher concentrations might adversely affect rumen fermentation. Gas and VFA production were greater at a Yucca saponins concentration of $75 \mathrm{mg} / \mathrm{l}$ compared with the control, but decreased at higher concentration ${ }^{(86)}$. The rate of gas production decreased in the presence of Yucca and Quillaja saponins, but increased in the presence of Acacia saponins when a mixture of hay and concentrate (70:30) was used as a substrate ${ }^{(46)}$. The authors ${ }^{(46)}$ also reported that Yucca, Quillaja and Acacia saponins either decreased the rate of gas production significantly or had a tendency to decrease it depending upon the dose levels when hay was used as a substrate. The potential extent of gas production was either not affected (Quillaja saponins) or decreased (Yucca and Acacia saponins) in this study ${ }^{(46)}$. A number of studies reported that saponins from different plants increased propionate and decreased acetate proportions ${ }^{(25,39,41,43,51,54,55,87-90)}$. Patra et al. ${ }^{\left({ }^{10}\right)}$ reported that extracts of Acacia concinna containing saponins, which inhibited protozoa number to the extent of $80 \%$, did not affect total VFA productions, but increased propionate production, and there was a decrease in the acetate:propionate ratio. The molar proportion of acetate was lower in sheep receiving the Yucca diets compared with the control diet, and molar proportions of butyrate and iso-acids were higher ${ }^{(35)}$. Similarly, an increased molar proportion of propionate concentration in the rumen by the Biophytum extract that contains saponins has been reported ${ }^{(19)}$. These characteristics of VFA pattern are often noted in studies with defaunated animals ${ }^{(58)}$. Conversely, Hussain \& Cheeke ${ }^{(41)}$ found a numerically lower propionate concentration in vivo with $75 \mathrm{ppm}$ of Yucca saponins. However, Valdez et al. ${ }^{(29)}$ and $\mathrm{Wu}$ et al. ${ }^{(40)}$ did not observe a significant change in propionate concentration in vivo up to 77 and $125 \mathrm{ppm}$, respectively, of Yucca saponins. The responses of saponins on rumen VFA production are often diet dependent. The study of Wang et al. ${ }^{(86)}$ clearly demonstrated that gas and total VFA productions from barley grain were increased by $Y$. schidigera, whereas they were reduced from lucerne hay. Kil et al. ${ }^{(91)}$ found a significant increase in propionate concentration in vitro when supplying $125 \mathrm{ppm}$ of Yucca saponins with a mixed forage-concentrate diet, but reported a marginal effect with a concentrate diet. Additionally, Cardozo et al. ${ }^{(92)}$ showed that Yucca saponins at dose levels up to $30 \mathrm{mg} / \mathrm{l}$ increased the molar proportion of propionate and reduced that of acetate at $\mathrm{pH}$ of $5 \cdot 5$, whereas no effect was noted at $\mathrm{pH} 7 \cdot 0$, which indicated that effects of saponins on VFA profiles might be modulated by rumen $\mathrm{pH}$.

\section{Methane production}

Methane produced during anaerobic fermentation in the rumen represents a feed energy loss and contributes to the greenhouse effect. Therefore, decreasing methane emission has been an important objective for ensuring the sustainability of ruminant production. Methane is produced normally during fermentation of feeds in the rumen by methanogenic archaea. The removal of protozoa can decrease methane production, as some populations of methanogens remain associated with protozoa as ectosymbionts and endosymbionts ${ }^{(57,93,94)}$. Theasaponin caused an increase in propionate production, while methane and isobutyrate production were decreased ${ }^{(89)}$.

In a study by Hess et al. ${ }^{(67)}$, Sapindus saponaria in Rusitec reduced methane production by $20 \%$, without affecting the methanogens relative to control and there was a $54 \%$ reduction in protozoa counts. This was confirmed in vivo - daily methane release was decreased by Sapindus saponaria supplementation in lambs fed basal diets of grass hay or grass and legume mixture (1:2 or $2: 1)$ along with concentrate $^{(27)}$. Agarwal et al. ${ }^{(54)}$ reported that the depression in methane production was $96,39.4$ and $20 \%$ with ethanol, water and methanol extracts of Sapindus mukorossi, respectively, compared with controls. Tea saponins deceased in vitro methane production by $13 \%$ at a concentration of $67 \mathrm{mg} / \mathrm{l}$ to $22 \%$ at a concentration of $133 \mathrm{mg} / \mathrm{l}$, whereas greater concentrations (200 and $267 \mathrm{mg} / \mathrm{l}$ ) had no further inhibitory effect on methane production ${ }^{(50)}$. Methane production also decreased linearly with increasing concentrations of Yucca saponins in an in vitro medium containing different substrates such as potato starch, maize starch and hay-concentrate ${ }^{(87)}$. However, saponins from Acacia concinna extracts did not affect methane production or DM digestibility, although it reduced protozoa numbers ${ }^{(10)}$. Similarly, $Q$. saponaria extract $(0.12,0.24$ and $0.36 \mathrm{~g}$ saponins per litre) did not influence in vitro methane production ${ }^{(55)}$ whereas $Y$. schidigera extract $(0,0.18,0.36$ and $0.54 \mathrm{~g}$ saponins per litre $)^{(55)}$ and whole Yucca plant $(0,15,30$ and $45 \mathrm{~g} / \mathrm{kg}$ DM equivalent to $0,0.023,0.046$ and $0.069 \mathrm{~g}$ saponins 
per litre) $)^{(25)}$ decreased in vitro methane production, with increasing concentrations of saponins ${ }^{(55)}$ accompanied by decreased protozoal numbers. Klita et al. ${ }^{(17)}$ demonstrated that saponin extract (27.8\% saponins) from lucerne root did not affect methane production in sheep when administered intra-ruminally at the rate of $0,1,2$ and $4 \%$ of DM intake although protozoal numbers decreased linearly with increasing concentrations of saponins.

It has been observed that the effect of Sapindus saponaria on methane was more pronounced in the defaunated (29\%) than faunated $(14 \%)$ rumen fluid, indicating that reduced methane production was not entirely due to associated depression in protozoal counts ${ }^{(67)}$. Again, Goel et al. ${ }^{(95)}$ noted that Sesbania sesban saponins decreased methanogen populations by $78 \%$ and the methane inhibition effect of Sesbania sesban was more pronounced in concentrate-based diets compared with roughage-based diets.

\section{Explaining the effects of saponins in modifying digestion and rumen fermentation}

The presence of protozoa in the rumen has been shown to stabilise rumen $\mathrm{pH}$ and decrease the redox potential of rumen digesta, which should indirectly stimulate the cellulolytic bacterial activity ${ }^{(96)}$. Furthermore, approximately one-fifth of fibre degradation is of protozoal origin $^{(97)}$. However, the engulfment and digestion of bacteria, fungal zoospores and archaea by protozoa causes a considerable proportion of microbial protein turnover in the rumen, decreasing the efficiency of protein utilisation in ruminants ${ }^{(98)}$. It has been recognised that many of the negative effects of defaunation may disappear as the bacterial and fungal populations increase and occupy the niches previously filled by the protozoa ${ }^{(58)}$, which may increase the efficiency of microbial protein synthesis and protein flow to the duodenum and improvement of $\mathrm{N}$ retention in animals ${ }^{(19)}$. All of the studies that have reported anti-protozoal properties of saponins or plants containing saponins were shown to cause partial defaunation. Veira et al. ${ }^{(99)}$ found that partially defaunated sheep $(8.3 \%$ of faunated sheep) were intermediate between observations in the completely defaunated and faunated sheep, and differences between partially and completely defaunated sheep were not significant. These findings suggest that responses of saponins to the efficiency of microbial protein synthesis and flow of amino acids to the intestine might be in between complete faunated and faunated animals depending upon the extent of the partial defaunation.

One of the pronounced effects of saponins reported in many of the studies is a decrease in ammonia concentration in the rumen, which may be primarily due to reduced bacterial lysis ${ }^{(98)}$ as a consequence of anti-protozoal properties of saponins. The inhibition of protozoa may also directly depress the proteolytic and deaminative activities of protozoal origin. The reduced proteolysis and deamination may also be the result of inhibition of bacteria by saponins. Moreover, it is possible that direct inhibition of microbial urease by saponins may lead to reduced ammonia concentrations in the rumen ${ }^{(100)}$. Additionally, the glycofractions of saponins are known to bind ammonia when concentrations of ammonia are low and when a high dose of saponins is added ${ }^{(44)}$. This might improve $\mathrm{N}$ efficiency by maintaining adequate rumen ammonia (trapping of rumen ammonia when ammonia concentrations are high after feeding and then slowly releasing it with the degradation of the glycofraction and desaturation of ammonia binding) for use during microbial protein synthesis when ammonia concentrations decrease $^{(36,40)}$. However, it has been shown that this ammonia binding appears to be negligible at ammonia concentrations typical of the rumen ${ }^{(44)}$. Collectively, all of these factors may result in reduced ammonia concentrations in the rumen. Although the greater bacterial activities may increase proteolysis and deamination, the contribution to the total ammonia pool in the rumen from this process could be minor due to the inclusion of saponins in diets. Therefore, it is apparent that the variations in ammonia concentrations due to the addition of saponins are caused by the different contributions that protozoa and bacteria make in different studies.

The ligno-cellulosic feedstuffs are degraded in the rumen by the synergistic activities of the bacteria, protozoa and fungi, with bacteria and fungi contributing approximately $80 \%$ of the degradative activity, and the protozoa only $20 \%{ }^{(97)}$. The most active fibrolytic bacteria $F$. succinogenes, Ruminococcus albus and Ruminococcus flavefaciens are generally considered as the primary organisms responsible for the degradation of plant cell walls in the rumen while Butyrivibrio fibrisolvens, Clostridium locheadii and Clostridium longisporum are some of the secondary fibrolytic bacteria ${ }^{(101)}$. Ruminal fungi produce a broad array of enzymes and generally degrade a wider range of substrates than do rumen bacteria ${ }^{(101,102)}$. Furthermore, ruminal fungi are able to degrade the most resistant plant cell wall polymers and the cellulases and xylanases produced by them are among the most active fibrolytic enzymes ${ }^{(103)}$. The ruminal protozoa also contribute to the degradation of plant cell wall polymers, but their contribution in fibre degradation is considered not as important as that of the bacteria and fungi $i^{(101,104)}$. Some studies have demonstrated that saponins decrease the passage rate of digesta from the rumen $^{(18)}$, which may increase the ruminal degradation of feeds. However, physiological effects of saponins are usually overridden by microbiological effects in the rumen $^{(18)}$ because of comparatively greater effects of saponins on microbial populations. Consequently, the positive effects of saponins on the digestibility of feeds in some studies might be attributed to the increased bacterial populations, whereas negative effects reported in other studies are due to decreased hydrolytic enzyme activities from protozoa and/or bacteria and fungi when saponins affect these populations. The substrate-dependent effect of saponins on digestibility might arise due to the effects of saponins on specific bacterial populations ${ }^{(41)}$. Wang et al. ${ }^{(59,86)}$ observed that supplementation with Yucca extracts might be beneficial to ruminants fed a high-grain diet. Yисса saponins were found to have a direct negative effect on cellulolytic bacteria while being harmless to amylolytic bacteria ${ }^{(59)}$. Additionally, Killeen et al. ${ }^{(105)}$ proposed that a surfactant or flocculent action of saponins on the feed constituents that alters the rate of digestion may account for the substrate-dependent nature of the effect of saponins on rumen digestibilities of feeds. 
The VFA concentration may generally follow the trend of feed digestion in the rumen. However, a part of the digested substrate may be partitioned to microbial mass, decreasing VFA concentrations ${ }^{(46)}$. Besides, saponins may affect intestinal cell permeability by forming complexes with sterol moieties in mucosal cell membranes ${ }^{(106)}$. It has also been reported that saponins may reduce active nutrient transport mechanisms and increase membrane permeability in the small intestine to facilitate uptake of materials to which the gut would normally be impermeable ${ }^{(106,107)}$. Moreover, saponins may reduce the transmural potential differences in the small intestine ${ }^{(108)}$. Thus, although there appears to be no study demonstrating the effects of saponins on absorption of VFA from the rumen, a reduction of VFA absorption would be possible, which may increase VFA concentrations in the rumen. It is well established that VFA in their undissociated forms are predominantly absorbed by passive transport mechanisms from the reticulo-rumen ${ }^{109)}$. But transport of dissociated VFA is coupled to the operation of an active transport mediated via a non-selective, electroneutral anion exchange system ${ }^{(109)}$. Therefore, considering the predominant role of passive transport on absorption of VFA, the effect of saponins on VFA transport is likely to be small.

An increase in the proportion of propionate production and a decrease in the acetate:propionate ratio have been observed. These characteristics of VFA profile are often noted in studies with defaunated animals ${ }^{(58)}$. Acetate and butyrate are the major endproducts of fermentation in ruminal protozoa ${ }^{(58)}$. Hence, a decrease in protozoal numbers by saponins may result in an increase in the proportions of propionate and the propionate:acetate ratio. Besides, saponins sometime stimulate the growth of Selenomonas ruminantium ${ }^{(59)}$, which is predominantly responsible for propionate production from succinate metabolism ${ }^{(110)}$.

Several factors may determine the effect of saponins on methanogen populations and methane production, which are discussed below. The direct effect of saponins on methanogen populations has not been proved so far, but cannot be ruled out. Nevertheless, some studies have demonstrated that saponins may decrease the activity of methane-producing genes or rate of methane production per methanogenic cell ${ }^{(51,57)}$. Many methanogens are found in both etco- and endosymbiotic associations with protozoa, which are responsible for up to $37 \%$ of rumen methanogenesis ${ }^{(93)}$. It has been estimated that a single protozoan cell may contain $10^{3}-10^{4}$ methanogens before feeding, decreasing to one to ten methanogens after feeding ${ }^{(94)}$. Sharp et al. ${ }^{(111)}$ reported that Methanobacteriaceae are the most abundant archaeal population both in the rumen fluid $(89.3 \%)$ and in a protozoal fraction $(99.2 \%)$, but it declined from 84 to $54 \%$ in fermenters with the loss of protozoa. Methanomicrobiales are the second most abundant archaeal family $(12.1 \%)$ in the rumen and they were found to be predominantly free-living. The Methanosarcinales can be free-living or associated with protozoa. Hence, defaunation, which disrupts the symbiotic relationship, has been suggested as a method to reduce methane production in ruminants. Contrary to this, protozoa engulf rumen methanogens ${ }^{(94)}$. As a result, there may be an increase in methanogen numbers not associated with protozoa when protozoa are washed out in the rumen. For instance, Sharp et al. ${ }^{(111)}$ showed that the numbers of Methanomicrobiales increased from 9.6 to $26.3 \%$ to replace the methanogens lost via protozoal displacement, whereas Methanosarcinales remained constant in the fermenters. Additionally, methane release may also be affected by saponins as a result of a reduced rate of methanogenesis via diminished activity of the methane-producing mcrA gene without changing the total methanogen population ${ }^{(51)}$. Since saponins favour the production of an increased proportion of propionate, the channelling of hydrogen from methanogenesis to propionate production may cause lower methane production. In contrast, methane production may be increased because of greater digestion of feeds and fibre components, as reported in some studies on saponins ${ }^{(24,29,33)}$, probably resulting from increased bacterial and fungal populations. Besides, as there is an inverse relationship between digesta passage rate and methane production, probably due to an increased fibre degradation in the rumen, and saponins decrease the rate of digesta passage $^{(17,18)}$, methane production may be increased as a result of an influence of saponins on passage rate. However, physiological effects of saponins appear to be insignificant compared with the microbiological effects ${ }^{(18)}$. The rate of digesta passage could be affected by saponins via changes in the motility of the digestive tract. Klita et al. ${ }^{(17)}$ demonstrated that the introduction of lucerne saponins inhibited rumen motility in sheep, while increasing the intestinal motility. No mechanism of action has yet been determined for the inhibitory effects of saponins on rumen motility. Klita et al. ${ }^{(17)}$ assumed that epithelial receptors in the luminal epithelium might be involved, which is more likely to be a result of interactions of saponins with the sterols in biological membranes. The mechanism of saponins on intestinal motility might be through the modulation of pace-making cells in the intestinal muscles that generate the rhythmic oscillations in the membrane potential and this modulation is mediated through nonselective cation channels and intracellular $\mathrm{Ca}^{2+}$ mobilisation in a protein kinase $\mathrm{C}$-independent manner, as demonstrated with ginseng saponins in mice ${ }^{(112)}$.

\section{Effects of saponins on ruminant performance}

The anti-protozoal effects of saponins would be expected to have mixed effects on ruminant productivity depending on the diets and the saponins involved. Although defaunation might decrease fibre degradation in the rumen ${ }^{(58)}$, it is generally agreed that removing or suppressing protozoa would result in increased ruminant performances ${ }^{(93)}$, particularly on a low-protein diet. The effect of defaunation depends on the balance between the energy and protein requirements of animals and nutrients supplied by diets. For example, defaunation is considered useful for animals with high protein requirements, but fed diets low in true protein, but not limited in energy ${ }^{(113,114)}$. Therefore, the effect of saponins is likely to be diet dependent. Inclusion of saponincontaining Enterolobium cyclocarpum foliage increased the body-weight gain from 93 to $115 \mathrm{~g} / \mathrm{d}$ in sheep fed oaten hay ${ }^{(20)}$ and from 19.8 to $29.7 \mathrm{~g} / \mathrm{d}$ in sheep fed Pennisetum clandestinum $^{(21)}$ and wool growth by $27 \%(20)$. The improvement of the performances of animals in these 
studies with the feeding of Enterolobium cyclocarpum might have been due to an increased absorption of amino acids from the intestine as a result of decreased protozoal numbers. Thalib et al. ${ }^{(115)}$ also reported that Sapindus extract added every $3 \mathrm{~d}$ to a rice straw diet improved the body-weight gain of sheep from 44.8 to $54.8 \mathrm{~g} / \mathrm{d}$. An improvement in the feed efficiency and economics was noted when grazing zebu cattle were fed with Yucca extract along with a urea molasses mineral block ${ }^{(116)}$. Supplementation of a maize silage-based diet with $150 \mathrm{mg}$ sarsaponin per $\mathrm{d}$ and $1 \%$ urea improved the body-weight gain of steers during the first $28 \mathrm{~d}$ of an experiment ${ }^{(31)}$, but there were no significant long-term (62 d) treatment effects, probably due to adaptation to saponins. From the above reports, it appears that saponins may enhance the performance of ruminants on roughage-based diets. Conversely, supplementation of concentrate-based diets with saponins generally did not show an improvement in ruminant performance. For instance, body-weight gain and feed efficiency in steers were not affected when an $88 \%$ concentrate diet containing $65 \%$ maize was supplemented with sarsaponin from Y. schidigera $^{(34)}$. Similarly, supplementation of a diet containing $90 \%$ concentrate with $150 \mathrm{mg} / \mathrm{kg}$ Yucca powder had no effect on the weight gain of male lambs ${ }^{(117)}$. The addition of $250 \mathrm{mg} / \mathrm{kg}$ Yucca extract to a mixed diet (45\% hay and $50 \%$ rolled barley, $5 \%$ soyabean meal) in steers ${ }^{(41)}$ and $30 \mathrm{mg} / \mathrm{kg}$ DM of sarsaponin (Y. schidigera extract) to a diet of hay-concentrate $(1: 1)$ in sheep ${ }^{(32)}$ also did not increase the daily gain. The inclusion of 40 and $60 \mathrm{mg}$ Quillaja saponins/kg in a $70 \%$ concentrate diet did not improve body-weight gain ${ }^{(118)}$. However, Quillaja saponins induced a higher response in the male lambs (256, 315 and $278 \mathrm{~g} / \mathrm{d}$ for control, 40 and $60 \mathrm{~g}$ saponins $/ \mathrm{kg}$, respectively) than the females (244, 239 and $203 \mathrm{~g} / \mathrm{d}$ for control, 40 and $60 \mathrm{~g}$ saponins $/ \mathrm{kg}$, respectively $)^{(118)}$, probably due to a greater supply of protein to male lambs, which have greater requirement of protein compared with female lambs.

There are reports that milk yields and the composition of milk from moderate- or high-yielding cows $(20-30 \mathrm{~kg} / \mathrm{d})$ are not improved by inclusion of Yucca or Quillaja extract in diets containing 10 to $20 \%$ crude protein ${ }^{(25,29,30,36,37,40,42)}$ Even supplementation of diets containing less than $10 \%$ protein with Yucca saponins $(0 \cdot 1 \mathrm{~g} / \mathrm{kg})$ did not affect milk production $^{(119)}$. In the experiments of Benchaar et al. ${ }^{(42)}$, Singer et al. ${ }^{(30)}$ and Holtshausen et al. ${ }^{(25)}$, rumen fermentation and protozoa numbers were also not affected by saponin treatment, probably due to the low doses of saponins used. Therefore, the lack of effect of saponins on milk production in some studies might be due to the administration of low levels of saponins, and consequent inefficacy to elicit rumen metabolism response, while in other studies, nutrient requirements are probably met from the diets without saponin supplementation. The effects of Yucca and Quillaja saponins on feed consumption are inconsistent. Some studies ${ }^{(37,42,41)}$ have reported a slight decrease from 2 to $6 \%$, and others ${ }^{(43)}$ did not find any effect of $Y$. schidigera supplementation on feed consumption. Holtshausen et al. ${ }^{(25)}$ reported that Yucca and Quillaja saponins increased DM intake, which resulted in a decrease of milk production efficiency. Contrary to the study of Holtshausen et al. ${ }^{(25)}$, Lovett et al. ${ }^{(37)}$ noted that Yucca extract supplementation (25 and $50 \mathrm{~g} / \mathrm{d}$ ) decreased feed intakes in dairy cows without affecting milk yields, thus increasing the efficiency of converting feedstuff to milk and in this study protozoal numbers were decreased by Yucca extract feeding. It is important to identify the feeding condition and animals' nutrient requirements that would show a beneficial response of saponins on ruminant production.

\section{Conclusion}

Plants or their extracts with high concentrations of saponins appear to have the potential to act as natural rumen manipulators. The primary effects of saponins are to modify the composition of rumen microbial populations, resulting in the modification of rumen fermentation. The most important effect of saponins in the rumen is to inhibit the ciliate protozoa, which might improve the efficiency of microbial protein synthesis by reducing microbial protein turnover, and protein flow to the duodenum. Saponins may inhibit methane production through defaunating actions and/or directly by decreasing the activities of methanogens such as the rate of methanogenesis or expression of methane-producing genes. Saponins may also selectively affect specific rumen bacteria and fungi, which may alter the rumen metabolism beneficially or adversely. The ammoniaadsorption and modulation of digesta passage in the rumen by saponins have also been implicated in altering the rumen metabolism, but their physiological responses are likely to be negligible compared with microbiological effects. The mechanisms and effects of saponins on the rumen microbial community and fermentation are interdependent depending upon the types and levels of saponins, composition of diets, microbial populations affected and adaptation of microbiota to saponins. Therefore, there is a need for comprehensive research based on the interactions among chemical structures of saponins, nutrient composition of diets and their effects on the rumen microbial ecosystem if a consistent beneficial effect of saponin inclusion in diets is ever to be achieved. It is important to identify the most bioactive saponins that will specifically inhibit protozoa and/or activities and numbers of methanogens and which may stimulate the beneficial bacteria and fungi. Although most saponins are considered quite safe when they are administered orally, certain kinds of saponins may exert toxic effects in the body, which must be tested in vivo in long-term experiments. The beneficial effects of saponins can be used extensively in various feeding systems if more active metabolites can be isolated and identified from plants or plant biotechnological tools can be employed to produce target bioactive principles.

\section{Acknowledgements}

The present research received no specific grant from any funding agency in the public, commercial or not-for-profit sectors.

The authors would like to thank two anonymous reviewers for their valuable suggestions, which greatly helped to improve the quality of this paper.

Both authors contributed equally to the paper.

The authors declare that they have no conflicts of interest. 


\section{References}

1. Molyneux RJ, Lee ST, Gardner DR, et al. (2007) Phytochemicals: the good, the bad and the ugly? Phytochemistry 68, 2973-2985.

2. Wallace RJ, McEwan NR, McIntosh FM, et al. (2002) Natural products as manipulators of rumen fermentation. Asian-Aust J Anim Sci 15, 1458-1468.

3. Wallace RJ (2004) Antimicrobial properties of plant secondary metabolites. Proc Nutr Soc 63, 621-629.

4. Patra AK (2004) Inhibition of ciliate protozoa and stimulation of fiber degrading microbes in the rumen of buffaloes by plant secondary metabolites. PhD Thesis, Indian Veterinary Research Institute, India.

5. Wina E, Muetzel S \& Becker K (2005) The impact of saponins or saponin-containing plant materials on ruminant production - a review. J Agric Food Chem 53, 8093-8105.

6. Benchaar C, Calsamiglia S, Chaves AV, et al. (2008) A review of plant-derived essential oils in ruminant nutrition and production. Anim Feed Sci Technol 145, 209-228.

7. Kamra DN, Patra AK, Chatterjee PN, et al. (2008) Effect of plant extract on methanogenesis and microbial profile of the rumen of buffalo: a brief overview. Aust J Exp Agric 48, $175-178$.

8. Patra AK \& Saxena J (2009) Dietary phytochemicals as rumen modifiers: a review of the effects on microbial populations. Anton Van Leeuwenhoek 96, 363-375.

9. Barton MD (2000) Antibiotic use in animal feed and its impact on human health. Nutr Res Rev 13, 279-299.

10. Patra AK, Kamra DN \& Agarwal N (2006) Effect of plant extracts on in vitro methanogenesis, enzyme activities and fermentation of feed in rumen liquor of buffalo. Anim Feed Sci Technol 128, 276-291.

11. Francis G, Kerem Z, Makkar HPS, et al. (2002) The biological action of saponins in animal systems: a review. Br J Nutr 88, 587-605.

12. Cheeke PR (1996) Biological effects of feed and forage saponins and their impacts on animal production. Adv Exp Med Biol 405, 377-385.

13. Cheeke PR (2000) Actual and potential applications of Yucca schidigera and Quillaja saponaria saponins in human and animal nutrition. J Anim Sci 77, 1-10.

14. Fenwick SB, Price KR, Tsukamoto C, et al. (1992) Saponins. In Toxic Substances in Crop Plants, pp. 285-327 [JPF D'Mello, CM Duffus and JH Duffus, editors]. London: The Royal Society of Chemistry.

15. Hostettmann K \& Marston A (1995) Saponins. Cambridge, UK: Cambridge University Press.

16. Vincken J-P, Heng L, de Groot A, et al. (2007) Saponins, classification and occurrence in the plant kingdom. Phytochemistry 68, 275-297.

17. Klita PT, Mathison GW, Fenton TW, et al. (1996) Effect of alfalfa root saponins on digestive function in sheep. J Anim Sci 74, 1144-1156.

18. Lu CD \& Jorgensen NA (1987) Alfalfa saponins affect site and extent of nutrient digestion in ruminants. J Nutr 117, 919-927.

19. Santoso B, Kilmaskossub A \& Sambodo P (2007) Effects of saponins from Biophytum petersianum Klotzsch on ruminal fermentation, microbial protein synthesis and nitrogen utilization in goats. Anim Feed Sci Technol 137, 58-68.

20. Leng RA, Bird SH, Klieve A, et al. (1992) Legume trees and other fodder trees as protein sources. In FAO Animal Production and Health Paper no. 102, pp. 177-191 [PL Pugliese, editor]. Rome: FAO.

21. Navas-Camacho A, Laredo MA, Cuesta A, et al. (1993) Effect of supplementation with a tree legume forage on rumen function. Livest Res Rural Develop 5 (epublication: http://www.cipav.org.co/lrrd/lrrd5/navas.htm).

22. Ivan M, Koenig KM, Teferedegne B, et al. (2004) Effect of the dietary Enterolobium cyclocarpum foliage on the population dynamics of rumen ciliate protozoa in sheep. Small Rumin Res 52, 81-91.

23. Baah J, Ivan M, Hristov AN, et al. (2007) Effects of potential dietary antiprotozoal supplements on rumen fermentation and digestibility in heifers. Anim Feed Sci Technol 137, 126-137.

24. Pen B, Takura K, Yamaguchia S, et al. (2007) Effects of Yucca schidigera and Quillaja saponaria with or without $\beta-1,4$ galacto-oligosaccharides on ruminal fermentation, methane production and nitrogen utilization in sheep. Anim Feed Sci Technol 138, 75-88.

25. Holtshausen L, Chaves AV, Beauchemin KA, et al. (2009) Feeding saponin-containing Yucca schidigera and Quillaja saponaria to decrease enteric methane production in dairy cows. J Dairy Sci 92, 2809-2821.

26. Abreu A, Carulla JE, Lascano CE, et al. (2004) Effects of Sapindus saponaria fruits on ruminal fermentation and duodenal nitrogen flow of sheep fed a tropical grass diet with and without legume. J Anim Sci 82, 1392-1400.

27. Hess HD, Beuret RA, Lotscher M, et al. (2004) Ruminal fermentation, methanogenesis and nitrogen utilization of sheep receiving tropical grass hay-concentrate diets offered with Sapindus saponaria fruits and Cratylia argentea foliage. Anim Sci 79, 177-189.

28. Diaz A, Avendan OM \& Escobar A (1993) Evaluation of Sapindus saponaria as a defaunating agent and its effects on different ruminal digestion parameters. Livest Res Rural Develop 5 (epublication: http://www.cipav.org.co/ lrrd/lrrd5/cefe.htm).

29. Valdez FR, Bush LJ, Goetsch AL, et al. (1986) Effect of steroidal sapogenins on rumen fermentation and on production of lactating dairy cows. J Dairy Sci 69, $1568-1575$.

30. Singer MD, Robinson PH, Salem AZM, et al. (2008) Impacts of rumen fluid modified by feeding Yucca schidigera to lactating dairy cows on in vitro gas production of 11 common dairy feedstuffs, as well as animal performance. Anim Feed Sci Technol 146, 242-258.

31. Mader TL \& Brumm MC (1987) Effect of feeding sarsaponin in cattle and swine diets. J Anim Sci 65, 9-15.

32. Sliwinski BJ, Kreuzer M, Wettstein HR, et al. (2002) Rumen fermentation and nitrogen balance of lambs fed diets containing plant extracts rich in tannins and saponins and associated emissions of nitrogen and methane. Arch Anim Nutr 56, 379-392.

33. Goetsch AL \& Owens FN (1985) Effects of sarsaponin on digestion and passage rates in cattle fed medium to low concentrates. J Dairy Sci 68, 2377-2384.

34. Zinn RA, Alvarez EG, Montano MF, et al. (1998) Influence of tempering on the feeding value of rolled corn in finishing diets for feedlot cattle. J Anim Sci 76, 2239-2246.

35. Santoso B, Mwenya B, Sar C, et al. (2006) Ruminal fermentation and nitrogen metabolism in sheep fed a silagebased diet supplemented with Yucca schidigera or Y. schidigera and nisin. Anim Feed Sci Technol 129, 187-195.

36. Wilson RC, Overton TR \& Clark JH (1998) Effects of Yucca schidigera extract and soluble protein on performance of cows and concentrations of urea nitrogen in plasma and milk. J Dairy Sci 81, 1022-1027.

37. Lovett DK, Stack L, Lovell S, et al. (2006) Effect of feeding Yucca schidigera extract on performance of lactating dairy cows and ruminal fermentation parameters in steers. Livest Sci 102, 23-32. 
38. Wang CJ, Wang SP \& Zhou H (2009) Influences of flavomycin, ropadiar, and saponin on nutrient digestibility, rumen fermentation, and methane emission from sheep. Anim Feed Sci Technol 148, 157-166.

39. Santoso B, Mwenya B, Sar C, et al. (2004) Effects of supplementing galacto-oligosaccharides, Yucca schidigera and nisin on rumen methanogenesis, nitrogen and energy metabolism in sheep. Livest Prod Sci 91, 209-217.

40. Wu Z, Sadik M, Sleiman FT, et al. (1994) Influence of yucca extract on ruminal metabolism in cows. J Anim Sci 72, $1038-1042$.

41. Hussain I \& Cheeke PR (1995) Effect of dietary Yucca schidigera extract on rumen and blood profiles of steers fed concentrate- or roughage-based diets. Anim Feed Sci Technol 51, 231-242.

42. Benchaar C, McAllister TA \& Chouinard PY (2008) Digestion, ruminal fermentation, ciliate protozoal populations, and milk production from dairy cows fed cinnamaldehyde, quebracho condensed tannin, or Yucca schidigera saponin extracts. J Dairy Sci 91, 4765-4777.

43. Hristov AN, McAllister TA, Van Herk FH, et al. (1999) Effect of Yucca schidigera on ruminal fermentation and nutrient digestion in heifers. J Anim Sci 77, 2554-2563.

44. Wallace RJ, Arthaud L \& Newbold CJ (1994) Influence of Yucca schidigera extract on ruminal ammonia concentration and ruminal microorganisms. Appl Environ Microbiol 60, $1762-1767$.

45. Wang Y, MaAllister TA, Newbold CJ, et al. (1998) Effect of Yucca schidigera extract on fermentation and degradation of steroidal saponins in the rumen simulation technique (RUSITEC). Anim Feed Sci Technol 74, 143-153.

46. Makkar HPS, Sen S, Blümmel M, et al. (1998) Effects of fractions containing saponins from Yucca schidigera, Quillaja saponaria and Acacia auriculoformis on rumen fermentation. J Agric Food Chem 46, 4324-4328.

47. Hristov AN, Ivan M, Neill L, et al. (2003) Evaluation of several potential bioactive agents for reducing protozoal activity in vitro. Anim Feed Sci Technol 105, 163-184.

48. Thalib A, Widiawati Y, Hamid H, et al. (1995) The effects of saponins from Sapindus rarak fruit on rumen microbes and host animal growth. Ann Zootech 44, Suppl., 161.

49. Newbold CJ, Hassan SME, Wang J, et al. (1997) Influence of foliage from African multipurpose tree on activity of rumen protozoa and bacteria. Br J Nutr 78, 237-249.

50. Hu WL, Liu JX, Ye JA, et al. (2005) Effect of tea saponin on rumen fermentation in vitro. Anim Feed Sci Technol 120, 333-339.

51. Guo YQ, Liu J-X, Lu Y, et al. (2008) Effect of tea saponin on methanogenesis, microbial community structure and expression of mcrA gene, in cultures of rumen microorganisms. Lett Appl Microbiol 47, 421-426.

52. Kamra DN, Singh R, Agarwal N, et al. (2000) Soapnut (reetha) as natural defaunating agent - its effect on rumen fermentation and in sacco degradability of jowar hay in buffaloes. Buffalo J 16, 99-104.

53. Monforte-Briceno GE, Sandoval-Castro CA, RamirezAviles L, et al. (2005) Defaunating capacity of tropical fodder trees: effects of polyethylene glycol and its relationship to in vitro gas production. Anim Feed Sci Technol 123-124, 313-327.

54. Agarwal N, Kamra DN, Chaudhary LC, et al. (2006) Effect of Sapindus mukorossi extracts on in vitro methanogenesis and fermentation characteristics in buffalo rumen liquor. J Appl Anim Res 30, 1-4.

55. Pen B, Sar C, Mwenya B, Kuwaki K, et al. (2006) Effects of Yucca schidigera and Quillaja saponaria extracts on in vitro ruminal fermentation and methane emission. Anim Feed Sci Technol 129, 175-186.

56. Teferedegne B, McIntosh F, Osuji PO, et al. (1999) Influence of foliage from different accessions of the subtropical leguminous tree, Sesbania sesban, on ruminal protozoa in Ethiopian and Scottish sheep. Anim Feed Sci Technol 78, 11-20.

57. Hess HD, Kreuzer M, Diaz TE, et al. (2003) Saponin rich tropical fruits affect fermentation and methanogenesis in faunated and defaunated fluid. Anim Feed Sci Technol 109, 79-94.

58. Williams AG \& Coleman GS (1997) The rumen protozoa. In The Rumen Microbial Ecosystem, pp. 72-120 [PN Hobson and CS Stewart, editors]. London: Blackie Academic and Professional.

59. Wang Y, McAllister TA, Yanke LJ, et al. (2000) Effect of steroidal saponin from Yucca schidigera extract on ruminal microbes. J Appl Microbiol 88, 887-896.

60. Russell JB \& Rychlik J (2001) Factors that alter rumen microbial ecology. Science 292, 1119-1122.

61. Sen S, Makkar HPS, Muetzel S, et al. (1998) Effect of quillaja saponins and Yucca schidigera plant extract on growth of Escherichia coli. Lett Appl Microbiol 27, 35-38.

62. Muetzel S, Hoffmann EM \& Becker K (2003) Supplementation of barley straw with Sesbania pachycarpa leaves in vitro, effects on fermentation variables and rumen microbial concentration structure quantified by ribosomal RNA-targeted probes. Br J Nutr 89, 445-453.

63. Wina E, Muetzel S \& Becker K (2006) The dynamics of major fibrolytic microbes and enzyme activity in the rumen in response to short- and long-term feeding of Sapindus rarak saponins. J Appl Microbiol 100, 114-122.

64. Wina E, Muetzel S, Hoffmann E, et al. (2005) Saponins containing methanol extract of Sapindus rarak affect microbial fermentation, microbial activity and microbial community structure in vitro. Anim Feed Sci Technol 121, $159-174$

65. Vinogradov E, Egbosimba EE, Perry MB, et al. (2001) Structural analysis of the carbohydrate components of the outer membrane of the lipopolysaccharide-lacking cellulolytic ruminal bacterium Fibrobacter succinogenes S85. Eur J Biochem 268, 3566-3576.

66. Sarkar M, Hamilton CJ \& Fairlamb AH (2003) Properties of phosphoenolpyruvate mutase, the first enzyme in the aminoethylphosphonate biosynthetic pathway in Trypanosoma cruzi. J Biol Chem 278, 22703-22708.

67. Hess HD, Monsalve LM, Lascano CE, et al. (2003) Supplementation of a tropical grass diet with forage legumes and Sapindus saponaria fruits: effects on in vitro ruminal nitrogen turnover and methanogenesis. Aust J Agric Res 54, 703-713.

68. Williams AG (1986) Rumen holotrich ciliate protozoa. Microbiol Rev 50, 25-49.

69. Sung WS \& Lee DG (2008) The combination effect of Korean red ginseng saponins with kanamycin and cefotaxime against methicillin-resistant Staphylococcus aureus. Biol Pharma Bull 31, 1614-1617.

70. Avato P, Bucci R, Tava A, et al. (2006) Antimicrobial activity of saponins from Medicago sp.: structure-activity relationship. Phytother Res 20, 454-457.

71. Khanna VG \& Kannabiran K (2008) Antimicrobial activity of saponin fractions of the leaves of Gymnema sylvestre and Eclipta prostrate. World J Microbiol Biotechnol 24, 2737-2740.

72. Makkar HPS \& Becker K (1997) Degradation of Quillaja saponins by mixed culture of rumen microbes. Lett Appl Microbiol 25, 243-245. 
73. Li Y, Du Y \& Zou C (2009) Effects of pH on antioxidant and antimicrobial properties of tea saponins. Eur Food Res Technol 228, 1023-1028.

74. Barile E, Bonanomi G, Antignani V, et al. (2007) Saponins from Allium minutiflorum with antifungal activity. Photochemistry 68, 596-603.

75. Oleszek WA (2000) Saponins. In Natural Food Antimicrobial Systems, pp. 295-324 [AS Naidu, editor]. Boca Raton, FL: CRC Press.

76. Yang C-R, Zhang Y, Jacob MR, et al. (2006) Antifungal activity of C-27 steroidal saponins. Antimicrob Agents Chemother 50, 1710-1714.

77. Teferedegne B (2000) New perspectives on the use of tropical plants to improve ruminant nutrition. Proc Nutr Soc 59, 209-214.

78. Odenyo AA, Osuji PO \& Karanfil O (1997) Effect of multipurpose tree (MPT) supplements on ruminal ciliate protozoa. Anim Feed Sci Technol 67, 169-180.

79. Mathison GW, Soofi-Siawah R, Klita PT, et al. (1999) Degradability of alfalfa saponins in the digestive tract of sheep and their rate of accumulation in rumen fluid. Can $J$ Anim Sci 79, 315-319.

80. Ogura S \& Sugawara K (1998) The disappearance of white clover saponins with ruminal degradation of white clover leaves. J Japan Soc Grassl Sci 44, 292-293.

81. Chahal SM \& Sharma DD (1991) In vitro ruminal degradation of mowrin - an incriminating factor of mahua (Bassia latifolia) seed cake. Indian J Anim Nutr 8, 143-144.

82. Meagher LP, Smith BL \& Wilkins AL (2001) Metabolism of diosgenin derived saponins: implications for hepatogenous photosensitization diseases in ruminants. Anim Feed Sci Technol 91, 157-170.

83. Flaoyen A \& Wilkins AL (1997) Metabolism of saponins from Narthecium ossifragum - a plant implicated in the aetiology of alveld, a hepatogenous photosensitization of sheep. Vet Res Commun 21, 335-345.

84. Flaoyen A, Wilkins AL, Deng D, et al. (2001) Ovine metabolism of saponins: evaluation of a method for estimating the ovine uptake of steroidal saponins from Narthecium ossifragum. Vet Res Commun 25, 225-238.

85. Flaoyen A, Wilkins AL \& Sandvik M (2002) Ruminal metabolism in sheep of saponins from Yucca schidigera. Vet Res Commun 26, 159-169.

86. Wang YX, McAllister TA, Yanke LJ, et al. (2000) In vitro effects of steroidal saponins from Yucca schidigera extract on rumen microbial protein synthesis and ruminal fermentation. J Sci Food Agric 80, 2114-2122.

87. Lila ZA, Mohammed N, Kanda S, et al. (2003) Effect of sarsaponin on rumen fermentation with particular reference to methane production in vitro. J Dairy Sci 86, 3330-3336.

88. Busquet M, Calsamiglia S, Ferret A, et al. (2006) Plant extracts affect in vitro rumen microbial fermentation. $J$ Dairy Sci 89, 761-771.

89. Ye JA, Liu J, Shi ZQ, et al. (2001) Effect of theasaponin on fermentation of cultured rumen fluid. Chinese J Anim Sci 37, 29-30.

90. Devant M, Anglada A \& Bach A (2007) Effects of plant extract supplementation on rumen fermentation and metabolism in young Holstein bulls consuming high levels of concentrate. Anim Feed Sci Technol 137, 46-57.

91. Kil JY, Cho NK, Kim BS, et al. (1994) Effects of Yucca extract addition on the in vitro fermentation characteristics of feed and feces, and on the milk yields in lactating cows. Korean J Anim Sci 36, 698-709.

92. Cardozo PW, Calsamiglia S, Ferret A, et al. (2005) Screening for the effects of natural plant extracts at different
$\mathrm{pH}$ on in vitro rumen microbial fermentation of a highconcentrate diet for beef cattle. J Anim Sci 83, 2572-2579.

93. Finlay BJ, Esteban G, Clarke KJ, et al. (1994) Some rumen ciliates have endosymbiotic methanogens. FEMS Microbiol Lett 117, 157-162.

94. Tokura M, Ushida K, Miyazaki K, et al. (1997) Methanogens associated with rumen ciliates. FEMS Microbiol Ecol 22, 137-143.

95. Goel G, Makkar HPS \& Becker K (2008) Effect of Sesbania sesban and Carduus pycnocephalus leaves and fenugreek (Trigonella foenum-graecum L.) seeds and their extracts on partitioning of nutrient from roughage and concentrate based feeds to methane. Anim Feed Sci Technol 147, 72-89.

96. Russell JB \& Wilson DB (1996) Why are ruminal cellulolytic bacteria unable to digest cellulose at low $\mathrm{pH}$ ? J Dairy Sci 79, 1503-1509.

97. Dijkstra J \& Tamminga S (1995) Simulation of the effects of diet on the contribution of rumen protozoa to degradation of fibre in the rumen. Br J Nutr 74, 617-634.

98. Wallace RJ \& McPherson CA (1987) Factors affecting the rate of breakdown of bacterial protein in rumen fluid. $\mathrm{Br} J$ Nutr 58, 313-323.

99. Veira DM, Ivan M \& Jui PY (1983) Rumen ciliate protozoa: effects on digestion in the stomach of sheep. J Dairy Sci $\mathbf{6 6}$, 1015-1022.

100. Ellenberger MA, Rumpler WV, Johnson DE, et al. (1985) Evaluation of the extent of ruminal urease inhibition by sarsaponin and sarsaponin fractions. J Anim Sci 61, Suppl. 1, 491.

101. Chesson A \& Forsberg CW (1997) Polysaccharide degradation by rumen microorganisms. In The Rumen Microbial Ecosystem, pp. 467-491 [PN Hobson and CS Stewart, editors]. London: Blackie Academic and Professonal.

102. Trinci APJ, Davies DR, Gull K, et al. (1994) Anaerobic fungi in herbivorous animals. Mycol Res 98, 129-152.

103. Forsberg CW \& Cheng K-J (1992) Molecular strategies to optimize forage and cereal digestion by ruminants. In Biotechnology and Nutrition, pp. 107-147 [DD Bills and SD Kung, editors]. Stoneham, UK: Butterworth Heinmann.

104. Lee SS, Ha JK \& Cheng KJ (2000) Relative contributions of bacteria, protozoa and fungi to in vitro degradation of orchard grass cell walls and their interactions. Appl Environ Microbiol 66, 3807-3813.

105. Killeen GF, Madigan CA, Connolly CR, et al. (1998) Antimicrobial saponins of Yucca schidigera and the implications of their in vitro properties for their in vivo impact. J Agric Food Chem 46, 3178-3186.

106. Johnson IT, Gee JM, Price K, et al. (1986) Influence of saponins on gut permeability and active nutrient transport in vitro. J Nutr 116, 2270-2277.

107. Knudsen D, Jutfelt F, Sundh H, et al. (2008) Dietary soya saponins increase gut permeability and play a key role in the onset of soyabean-induced enteritis in Atlantic salmon (Salmo salar L.). Br J Nutr 100, 120-129.

108. Oleszek W, Nowacka J, Gee JM, et al. (1994) Effects of some purified alfalfa (Medicago sativa) saponins on transmural potential difference in mammalian small intestine. J Sci Food Agric 65, 35-39.

109. Gabel G \& Sehested J (1997) SCFA transport in the forestomach of ruminants. Comp Biochem Physiol 118A, 367-374

110. Wolin MJ, Miller TL \& Stewart CS (1997) Microbemicrobe interactions. In The Rumen Microbial Ecosystem, pp. 467-491 [PN Hobson and CS Stewart, editors]. London: Blackie Academic and Professonal. 
111. Sharp R, Ziemer CJ, Stern MD, et al. (1998) Taxon-specific associations between protozoal and methanogen populations in the rumen and a model rumen system. FEMS Microbiol Ecol 26, 71-78.

112. Kim SH, Parajuli SP, Yeum CH, et al. (2007) Effects of ginseng total saponins on pacemaker currents of interstitial cells of cajal from the small intestine of mice. Biol Pharm Bull 30, 2037-2042.

113. De Smet S, Demeyer DI \& van Nevel CJ (1992) Effect of defaunation and hay:concentrate ratio on fermentation, fibre digestion and passage in the rumen of sheep. Anim Feed Sci Technol 37, 333-344.

114. Eugene M, Archimede H \& Sauvant D (2004) Quantitative meta-analysis on the effects of defaunation of the rumen on growth, intake and digestion in ruminants. Livest Prod Sci $\mathbf{8 5}, 81-97$.

115. Thalib A, Widiawati Y, Hamis H, et al. (1996) The effects of saponin from Sapindus rarak fruit on rumen microbes and performance of sheep. J Ilmu Ternak-dan Veteriner 2, $17-21$.

116. Mirza IH, Khan AG, Azim A, et al. (2002) Effect of supplementing grazing cattle calves with urea-molasses blocks, with and without Yucca schidigera extract, on performance and carcass traits. Asian-Aust J Anim Sci 15, 1300-1306.

117. Gorgulu M, Yurtseven S, Unsal I, et al. (2004) Effect of Yucca powder on fattening performance of male lambs. J Appl Anim Res 25, 33-36.

118. Bosler DA, Blummel M, Bullerdieck P, et al. (1997) Influence of a saponin-containing feed additive on mass development and carcass evaluation of growing lambs. Proc Soc Nutr Physiol 6, 46.

119. Sliwinski BJ, Kreuzer M, Sutter F, et al. (2004) Performance, body nitrogen conversion and nitrogen emission from manure of dairy cows fed diets supplemented with different plant extracts. J Anim Feed Sci 13, 73-91. 